\title{
REVISTA DE HISTORIA
}

Publicação Trimestral

ANO XXV

Volume L

Tомо II

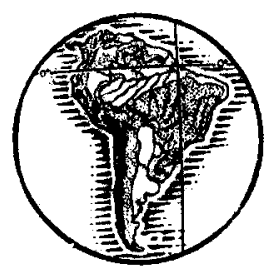

SĀO PAULO - BRASIL

1974 



\section{NÚMERO JUBILAR}

Organizado pela Prof. Maria Regina da Cunha Rodrigues. 

Volume L - REVISTA DE HISTÓRIA - Ano XXV

\section{O ATUAL E O INATUAL NA OBRA DE LEOPOLD VON RANKE.}

\section{SERGIO BUARQUE DE HOLANDA}

da Universidade de São Paulo.

Nascido em ambiente luterano e crescido na atmosfera ainda meio acanhada da Prússia oitocentista dos Hohenzollern e de Bismarck, tão admiravelmente retratada nas novelas de Fontane, Leopold von Ranke mal se deixou impregnar por esses influxos. O nome de Deus aparece muitas vezes em suas páginas, mas aparece antes como concessão ao protestantismo em que foi criado, do que como sinal de um intenso sentimento religioso: se desaperecesse ou fosse substituido por alguma fórmula profana, não lhe faria falta. Quanto ao seu prussianismo, há nele alguma coisa de compulsório. Oriundo da Turíngia, antes de ser incorporada sua terra à monarquia da casa de Brandenburgo, o fato é que, nobilitado embora e convertido em historiador oficial dessa monarquia, nunca há de ser contaminado pelos fervores que desperta em volta dele a crescente pujança do reino da Prússia e, afinal, do 2 \% Reich. Foi um motivo para os atritos que teve com seu rival Droysen e seu discípulo Sybel, que dele se separará para alinhar-se na escola histórica prussiana.

O inglês e católico Lord Acton quase lamentava não poder achar em Ranke um prussiano mais patriota e um protestante mais devoto. $O$ que o mestre de Cambridge censurava principalmente nele, como aliás na maioria dos intelectuais e homens públicos alemães da sua época, exceção feita dos católicos liberais e dos socialistas, era, alem disso, o pouco caso alarmante que, a seu ver, pareciam mostrar pelos princípios morais perenes.

Quando em 1882 escrevia sobre isso a Döllinger, ainda não tinha entrado em circulação, ao menos com o conteudo positivo que tomará mais tarde, o nome "historismo" que, se não servia para designar quase tudo quanto abominava Acton, foi constantemente associado à indiferença ou ao relativismo ético. Indicando antes uma mentalidade do que um método, e aparecendo na jurisprudência, na teologia, na 
filosofia, na filologia, antes de se manifestar na historiografia, sempre teve na Alemanha sua grande fortaleza, e mesmo quando fertilizou o pensamento da Europa ocidental, guardou a marca de origem (1). Se é certo que, em sua oposição ao jusnaturalismo do século XVIII, pareceu filiar-se por um lado ao pensamento contra-revolucionário, não é menos verdade que tambem teria justificado e fundado em grande parte a auto-afirmação sediciosa do princípio das nacionalidades entre povos oprimidos, que parece já despontar em Herder. Alem disso está presente, não apenas na obra do jovem Hegel qui genuit Marx, mas tambem nas especulações daquela Santa Família, a que Marx se achou ligado antes de a combater.

Ao reagir contra o naturalismo ahistórico, onde geralmente se presumia, em suas diferentes manifestações, uma estabilidade obrigatória da natureza humana e a necessidade de certos postulados eternos e universalmente válidos, a nova corrente de pensamento levava a uma reflexão individualizante e historizante, isto é, tendente a mover-se de acordo com o curso imprevisivel da história. Se não é possivel negar os progressos que a visão historista acarretou para o conhecimento da vida e da história humanas, pode-se bem imaginar que, dissipando em grande parte os elementos normativos e o terreno firme que tiravam seu sustento das teorias do Direito Natural, o que em seu lugar se instalou foram forças inéditas e mutáveis, capazes, naturalmente, de conduzir àquele relativismo ético de que falou Acton. "Ausência de convicções", "anarquia dos valores": são esses alguns dos labeus ainda hoje jogados sobre o historismo, quando o não fazem responsavel pelas deformações patológicas verificadas na história recente. A increpação é, quando menos, discutivel, pois a "razão de Estado" antecede de muitos séculos o nascimento da Realpolitik, e a fúria delinquente de Hitler não fica muito longe da virtude enlouquecida de Robespierre.

Procurando aprofundar mais o problema, é o caso de perguntar quais as teorias que, nascidas depois do historismo, dele independentes e muitas vezes opostas a ele, não podem ser acusadas de indiferença e neutralidade diante dos princípios éticos tradicionais. Do moderno em-

(1). - As formas "historismo" e "historicismo" foram por longo tempo intercambiáveis, ao menos fora dos paises de língua alemã. Nestes a primeira prevaleceu. Ultimamente, porem, apoderou-se da segunda o filósofo Karl Popper, e o racionalismo crítico anglo-americano, para aplica-lo às várias teorias que propõem previsóes historicas e que as julgam indispensáveis em qualquer orientação científica da vida política, o que tem dado lugar a não poucas confusões. Entre esses "historicistas", que Popper e Hayek descreveram e combateram, estão, ao lado de Hegel e Marx, tambem Augusto Comte e Stuart Mill, para só falar nesses. No intuito de evitar a confusão, adota-se aqui a forma "historismo", diverso e, em alguns pontos, contrário, ao "historicismo" de que falou Popper. 
pirismo lógico, por exemplo, e de todas as teorias englobadas sob o rótulo, as vezes incorreta, de nóo-positivismo, que puderam contribuir tão eficazmente para despojar a ciência, em particular a linguagem da ciência, de todas as excrescências que não se sustentam diante de uma análise lógica e semântica rigorosa, quem dirá que ofereceu ou, sequer, podem oferecer, elementos de uma ética normativa? A ciência, em si, é forçosamente neutra do ponto de vista moral. Quem diga que um ato é moralmente louvavel ou reprovavel, profere uma sentença que, escapando às possibilidades de escrutínio científico, não se sujeita, às categorias do verdadeiro e do falso. Desse ponto de vista, os problemas morais, como as questões metafísicas, não chegam mesma a existir, pois pertencem de fato aos pseudo-problemas. Não é forçoso, entretanto, condenar tais teorias com o fundamento de que sua isenção e neutralidade na esfera moral pode produzir frutos ominosos. Houve, contudo, quem se servisse dessas razōes pára condena-las, dizendo que o vazio deixado com o abandono dos "valores humanos fundamentais" pode ser eventualmente preenchido pela acquiescência tranquila às virtudes da violência ou das doutrinações fascistas, e citou mesmo, a esse propósito, a popularidade alcançada em nosso tempo pela divinização do Estado, do Partido, da Raça, da Pátria (2) . E tambem essa, sem tirar nem por, a increpação dos que querem vislumbrar no historismo uma indiferença pelos valores humanos universais, que levaria à busca de valores menos ou nada universais, como os que se concretizam no racismo ou no nacionalismo exacerbado.

Defendendo Ranke e a tendência historista que ele representou, contra um escritor que pretendera achar no "quietismo político" do alemão meio caminho para a ascenção do nacional-socialismo, um historiador de nosso tempo mostrou a injustiça de semelhante juizo, já que não existe em toda a obra rankeana o que possa autoriza-lo (3). Admite contudo o mesmo autor, que a passividade de Ranke, e em dado lugar deixa escapar a palavra "amoralismo", pudesse levar alguns historiadores a não reconhecer a existência de padrões ou códigos morais extranhos e transcententes ao objeto do estudo histórico. Mas acha admiravel, por outro lado, sua capacidade de serena observação, o empenho de tudo compreender, a perfeita receptividade a fenômenos diversos daqueles que deveriam ter a sua aprovação pessoal: do protestante em face do papado, do alemão em face da monarquia absoluta na França ou da monarquia parlamentar na Inglaterra, às vezes do conservador em face da Revolução francesa. São qualidades, essas,

(2). - Cf. C. E. N. Joad, A Critique of Logical Positivism, Chicago, The University of Chicago Press, 1950 , págs. 140 e segs.

(3). - Peter Geyl, Debates with Historians. Cleveland-New York. 1964, págs. 26 e 28 . 
que lograram exercer generosa influência sobre a civilização do século XIX e se acham no polo oposto à doutrinação de homens que cinquenta anos depois da morte de Ranke, mergulhariam a Alemanha e o mundo na catástrofe. Não deixa de lembrar Geyl, em defesa do historiador germânico, aquela "sua famosa frase sobre o primado da política externa", para admitir que pode ter consequências perigosas, devido sobretudo ao cunho idealista com que foi apresentada. Apenas Ranke jamais escreveu a "famosa frase", que the tem sido atribuida. Quem a escreveu foi Dilthey, a fim de tentar caracterizar certo traço da historiografia rankeana. Um escritor que se notabilizou por seus estudos sobre a gênese do historismo, observa, entretanto, que tal caracterização deixa de lado a questão da política interna dos Estados, que é consideravel na mesma historiografia, onde o que importa é a ação recíproca entre ela e a política externa (4). Isso está dito, aliás, e quase nos mesmos termos, tanto na História Inglesa como, e principalmente, na Conversa Politica.

Quanto à capacidade de omitir-se diante dos sucessos históricos, de não julgar, não moralizar, não tomar partido, se para muitos constitui uma das grandes virtudes de Ranke, há quem a julgue imperdoavel defeito. E aliás uma das razões das críticas de Acton, por exemplo, que ve nessa neutralidade um indício de insensibilidade moral, não apenas no escritor como no homem. Certa vez chega ele a citar, aprovando-a, uma opinião atribuida a Montalembert sobre o mestre de Berlim:

"Grande talento, espírito pequenino" (5).

Acomodatício, contemporizador, avesso, até diante dos íntimos, a dar opiniões que the granjeassem desafetos, acontecia-lhe, não raro, incompatibilizar-se com liberais e conservadores, que the imputavam tibieza de carater. Como tivesse aceito do seu governo um posto de confiança, ninguem esperaria, aliás, que entre as duas lealdades, a que o prendia à Casa de Brandenburgo e a que devia ao seu mister de historiador, tivesse a audácia de sacrificar a primeira. Para ele, embora em escritos que se situam à margem de sua obra central, o ensaio sobre as Grandes Potências, por exemplo, se mostrasse sobretudo um patriota alemão e prussiano, em geral o problema simplesmente não existia. Numa situação que o forçasse a definir-se, tinha como refugiar-se no seu santo impersonalismo. No livro $7^{\circ}$ da História Prussiana escreveu sobre as dúvidas surgidas quanto à legitimidade da

(4). - Friedrich Meinecke, Aphorismen und Skizzen zur Geschichte. Stuttgart. K. F. Koehler Verlag, 2a. ed., págs. 61 e seg.

(5). - Ignaz von Döllinger, Briefwechsel mit Lord Acton. Munique. C. H. Beck'sche Verlagbuchhandlung, vol. 19\%, 1963, pág. 78. 
ascenção de Maria Tereza ao trono imperial, que deram pretexto a Frederico II para invadir terras da Coroa da Áustria, arrebatando-lhe a Silésia, que

"felizmente não compete a quem escreve obra histórica, pronunciar-se a respeito de casos jurídicos controvertidos: em condições tais, mesmo as palavras mais cautelosas podem limitar sua imparcialidade".

Explicações dessa ordem nem sempre seriam convincentes; a prova está naquele juizo de Montalembert, endossado por Acton, sobre o "espírito pequenino" de Ranke. Tambem seu último assistente em Berlim comunicaria a Meinecke a impressão de que ele era um "homem pequenino". Que o adjetivo indicava uma falha de carater, é o que se depreende de carta do mesmo Meinecke (6). Não precisaria este apelar para testemunho alheio se quisesse aludir à pequenês física bem notória do historiador, que, de resto ele conheceu pessoalmente. Tambem Burckhardt usa do mesmo adietivo por mais de uma ocasião em correspondência particular, a propósito de Ranke, e quando o chama de "homem pequenino", tambem não quer referir-se à sua estatura (7) . Assim é que recorre à expressão a propósito de episódio testemunhado em Paris, numa recepção que ofereceu Thiers, por um alemão que o narrou a ele Burckhardt. Segundo essa testemunha, pusera-se, em dado momento, o dono da casa, a falar, em termos desrespeitosos e pérfidos, do defunto rei (Frederico Guilherme III da Prússia) e da rainha Luisa, num grupo onde estava Ranke, que tudo ouviu sem protesto. E possivel, acrescentou o informante, que o francês quisesse apenas provocar alguma notícia utilizavel num livro que tinha em preparo. Se isso é certo, foram baldados os seus trabalhos, porque o "homenzinho", ignorando a presença do compatriota que não era de suas relações, e cuidando que não estava sendo observado, julgou mais comodo fazer-se desentendido.

"Agora", comenta Burckhardt, "quando sair a história do Império, de Thiers, com as mesmas críticas ao rei velho e à rainha, já podemos saber quem é o culpado".

Perto de trinta anos mais tarde, num novo encontro entre Ranke e Thiers, dessa vez em Viena e durante a guerra franco-prussiana, ex-

(6). - Friedrich Meinecke, Ausgewälter Briefwechsel. Stuttgart. K. F. Koehler Verlag, 1962, pág. 545.

(7). - Jacob Burckhardt, Briefe, vol. 29, Basiléia, Benno Schwabe \& Co., Verlag, 1952, págs. 20 e 25. 
plicou o primeiro que a luta não se travava então contra Luis Napoleão, e muito menos contra a França, e sim contra Luís XIV, que, aproveitando uma hora dificil para o Império, anexou Estrasburgo. Sem se deixar convencer pelo argumento de que tamanho recuo no tempo levaria a uma transformação completa no mapa da Europa, declarou que as reivindicações do vencedor deveriam limitar-se à Alsácia, onde prevaleciam a língua e cultura alemãs; quanto à Lorena, o mesmo já não ocorria, por conseguinte achava justo que continuasse com os franceses. Logo depois, porem, quando soube que tambem a Lorena iria fazer parte do novo Império alemão, mudou de parecer e disse que essa conquista atendia à justiça histórica. E bem possivel que, fiel súdito da monarquia dos Hohenzollern, fizesse Ranke suas reservas íntimas ao rumo por onde iam levando seu pais, mas evitava manifestar-se a respeito. Ao menos num caso, segundo parece, desviou-se dessa regra, e o resultado, por pouco, não comprometeu sua situação pessoal. Em 1847, fiado aparentemente na intangibiildade que the dava a fama de seu alto saber, tentou intervir junto a um príncipe no sentido de não entrar em vigor certo edito, que lhe parecia sumamente imprudente naquela fase pré-revolucionária que atravessava a Prússia (8). Procurou-o para isso numa ocasião em que se achavam em companhia do príncipe vários ministros e altos dignitários. Mal exprimiu, porem, sua opinião e todos os presentes se retrairam, como se estivessem em presença de um democrata pestífero.

Se em ocasiões tais podia transigir, como transigiu no caso, não se conformava com a menor crítica aos princípios de isenção que julgava próprios do ofício do historiador. Assim é que, tendo publicado seu livro sobre a Alemanha ao tempo da Reforma e, entre os que o foram saudar por esse motivo, apareceu um especialista na matéria, tratando-o de colega, retrucou secamente que se considerava historiador, não apologeta. Num luterano declarado, é curioso, aliás, que se referisse à confissão de Augsburgo, como quem lamenta o ter-se perdido com ela uma oportunidade única de reunificação da Igreja . E que, apesar de divergências secundárias, até o Sumo Pontífice chegara a admitir a aceitação no essencial da Confessio, enquanto, do outro lado, Melanchton se mostrou favoravel a concessões que permitissem o acordo, e o próprio Lutero não lhes era adverso. No entender de Ranke, uma posição exclusivista em favor de Lutero e da Reforma, alem de contrariar sua teoria dileta da fundamental unidade dos povos latinos e germânicos, entraria em conflito com seu ideal de perfeita neutralidade nos estudos históricos.

(8). - Veit Valentin, Geschichte der Deutschen Revolution von 18481949, $1^{\circ}$ vol., Berlim, Verlag Kiepenheuer \& Witsch, 1970, pág. 65. 
Foi esse ideal que, ainda no pórtico de sua carreira de historiador, ele exprimiu numa fórmula que logo se celebrizaria. Disse então que o verdadeiro mister do historiador não consiste, como outros presumiam, no querer faze-lo juiz supremo do passado, a fim de instruir os contemporâneos em benefício das vindouras gerações. Quem quer que se ocupe da história, ajuntou, em vez se propor tão alta missão, deve contentar-se com ambições mais modestas. $O$ que se propõe ele 6 apenas mostrar (o sucedido) "tal como efetivamente sucedeu". Estas últimas palavras - "tal como efetivamente sucedeu": wie es eigentlich gewesen - parecem a muitos resumir o principal da contribuição historiográfica de Ranke. E uma fórmula sem dúvida infeliz, porque sua redação pode dar margem a interpretações que não correspondem ao pensamento do autor e, em muitos casos, são radicalmente opostas a esse pensamento, tal como foi desenvolvido e realizado ao longo de toda sua obra.

Expresso primeiramente em 1824, o princípio será retomado com mais clareza trinta anos depois, na introdução ao livro $5^{\circ}$ da História Inglesa. Nessa introdução, confessa que desejaria

\footnotetext{
"como que apagar-se nos seus escritos, para só poderem falar aquelas poderosas forças que, ao longo dos séculos, ora se unem e se misturam, ora se chocam em sangrentos combates, mas trazem no bojo, apesar disso, alguma solução, ao menos momentânea, para os grandes problemas do mundo europeu. E evidente que semelhante propósito não se acha ao alcance de toda gente".
}

O espetáculo que ele vê desenvolver-se ao longo dos séculos, nem sempre é um espetáculo público, e para evidencia-lo são necessários recursos de que Ranke dispunha notavelmente e que lhe permitiam, sem afetação retórica, organizar numa ordem plausivel o emaranhado de acontecimentos muitas vezes invisivel a olho nú. Dele se disse que, entre os historiadores, foi o maior escritor da Alemanha. E é a arte consumada do escritor de raça o que faz com que, depois de apreender os fatos particulares, saiba revive-los em suas pulsações, para que se integrem, afinal, em quadros amplos, onde ganham nova dimensão e significado mais alto. Ao menos por esse lado, não se pode dizer que consiga omitir-se ou apagar-se no que escreveu.

Um historiador de nossos dias observa, a esse propósito, a parte de elaboração e de criação que assim se introduz na obra rankeana. Com isso, e não só com isso, ele é o oposto de um simples cronista, contente com oferecer uma exposição circunstanciada e meticulosamente fiel dos fatos, tais como eles podem aparecer à primeira vista . 
E lembra o seu tratamento da Reforma, que visa a apresenta-la como um todo, que passa a ter vida própria e tornar-se mais plenamente inteligivel quando o historiador consegue mostrar as etapas do movimento em sua intrínseca unidade (9). Porque os contemporâneos da Reforma só podiam ve-la e vive-la como a veria e viveria um cronista, isto é, uma sucessão inumeravel de acontecimentos isolados e mal articulados entre sí. O que the importa é desvendar as grandes unidades de sentido, que irão dar àqueles sucessos sua verdadeira significação histórica. Acontece, diz o mesmo autor, que as grandes unidades de sentido não se apresentam diretamente, ao primeiro relance, em contraste com o que se pode dar nas criações artísticas, como o Fausto de Goethe, ou a Paixão segundo São Mateus, de Bach, ou os Apóstolos de Dürer, mas patenteiam-se verdadeiramente e adequadamente se organizadas por um historiador.

Dilthey, que foi historiador, mas foi sobretudo filósofo, pode ver em Ranke, por esse motivo, o incomparavel mestre da história encarada com objetividade e universalidade. Outras figuras capitais tem havido, acrescenta, entre os grandes historiadores da Alemanha: há os que, como Hegel, são dotados de mais profunda visão metafísica ou, como Niehbur, se mostram mais construtivos para a nacionalidade. Ranke, à primeira vista, deslisa na superfície dos acontecimentos ou não parece atinar com a noção das causas e, com tudo isso, é o grande mestre: em vez de ir às raizes que pudessem esclarecer, vai diretamente aos momentos culminantes, para apreende-los em suas conexões universais ... (10). E acrescenta:

"É o grande épico, outro Heródoto entre os historiadores. Vive em meio à multiplicidade dos acontecimentos. Tem constantemente presente as forças que acompanham e assistem os indivíduos, o Estado, enfim todas as manifestações coletivas. Discerne os momentos críticos, saindo do particular para o geral, que tudo envolve. A sua memória prodigiosa, que logra captar o que há de mais complexo na história, faz com que, em cada apreensão, a parte viva no todo, e seja considerada, não de modo abstrato, mas com plena consciência das relações de significado existentes entre ela e o conjunto: essa é a própria essência da sua exposição".

(9). - Theodor Schieder, "Die Darstellngsform der Geschichtswischaft", Geschichte als Wissenschaft. Munique-Viena. R. Oldenbourg, 1968, págs. 115 e seg.

(10). - Wilhelm Dilthey, "Erinnerung an Deutsche Geschichtsschreiber", Gesammelte Schriften. Vol. XI. Stuttgart, B. G. Teubner Verlagsgeselschaft, 1965, pág. 217. 
Sua fórmula tão mal interpretada, muitas vezes tem ainda outro alvo: forçar a eliminação, tanto quanto possivel, de pontos de vista pessoais que desfigurem o verdadeiro conteudo. Prende-se tudo isso a um empenho maior, que é o de fundar os estudos de sua especialidade sobre métodos rigorosamente científicos. A tal ponto que suas salas de aula se viram convertidas em autênticos laboratórios, que lhes deram desde cedo renome universal. Foi ele quem criou para os estudos históricos o sistema dos seminários, que aos poucos iriam proliferar em outros paises. Ao mesmo tempo desenvolveu recursos de pesquisa e crítica das fontes, adaptando para isso. à História, processos já em uso antes dele entre filólogos e exegetas da Bíblia. Pode-se perguntar até onde caberia nas possibilidades humanas o alcançarem-se por esses e outros meios, aquela visão perfeitamente neutra que, com base no estudo acurado da documentação, tornasse possivel aflorar finalmente a verdade histórica sem mácula. Ranke tinha consciência das dificuldades próprias da empresa que se propôs. Ao prefaciar as analectas de sua História Inglesa, tocou no assunto para dizer:

"O que proponho aquí é um ideal, e dirão que é impossivel converte-lo em realidade". Não importa. "O importante é ter podido mostrar o caminho certo", escreve, "e chegar a algum resultado que se sustente até mesmo em face das investigações e críticas que possam vir depois".

Para que a História alcançasse o estatuto científico, pareceu-lhe necessário que fizesse sacrifícios, e que seu campo se delimitasse rigorosamente. Assim como ao historiador não compete erigir-se em juiz ou moralizar, tambem não lhe cabe filosofar. A separação entre história e filosofia não é uma exclusividade sua, e em nossos dias voltou a ser defendida com ênfase por um renovador dos estudos históricos na França (11). A posição de Ranke acerca das relações entre a história e a filosofia tem dado lugar a interpretações quase tão discrepantes entre si como as que tem sugerido a fórmula do wie es eigentlich gewesen. Em estudo recente sobre a imagem de Ranke no pensamento histórico da Alemanha e dos Estados Unidos, foi dito por exemplo que, ao tempo de sua morte, a idéia que se passou a formar dele entre autores norte-americanos, diversa da que se vem ultimamente desenvolvendo, depois do influxo de professores europeus imigrados, prendia-se aos seus métodos de ensino e de pesquisa, que correspondiam bem ao desejo de dar respeitabilidade científica à história. Transplan-

(11). - Cf. Lucien Febvre, "Examen de Conscience d'une Histoire et d'un Historien", Combats pour l'Histoire. Paris. Librairie Armand Colin, 1953, pág. 4, e "Vers une Autre Histoire", ibid., pág. 433. 
taram-se para a América do Norte os seminários, e o nome de Ranke passou ali a ser identificado, pelas mais diversas correntes, com a história científica, e assim continuaria a se-lo por várias décadas. Seria ele, verdadeiramente, o "pai da ciência da história", e chegou-se a associa-lo curiosamente ao positivismo. Para os historiadores alemães, ao contrário, Ranke passou a tornar-se a antítese do empirismo não filosófico, e com raizes no idealismo (12). Só agora, nas duas últimas décadas ou pouco mais, a idéia norte-americana do legado rankeano começa a sofrer uma revisão que tende a aproxima-la da idéia germânica.

Embora seja inegavel que, formado no clima do idealismo filosófico, dessa formação seja marcada toda a sua obra, é possivel que, por oposição a Hegel, seu colega na Universidade de Berlim, o próprio Ranke se tenha incumbido de difundir uma imagem de seu legado que o apresentaria como interessado em emancipar a historiografia dos construtores de grandes sistemas filosóficos. Certamente não foi ele um historiador filósofo, como o foi de algum modo o seu grande contemporâneo e rival Droysen, nem, e muito menos, o que se chamaria uma cabeça filosófica. Defendia-se, entretanto, dos que o acusaram de indiferente ou mesmo hostil à filosofia. Em 1830, escrevendo de Veneza ao amigo Heinrich Ritter, observava:

"Acusam-me de falta de seriedade filosófica ou religiosa. Com toda razão se a palavra seriedade significa o agarrar-se alguem à primeira opinião expressa ou representada de maneira sistemática. Parece-me, risivel, entretanto, dizerem que não me interessam as questões filosóficas ou religiosas. Foram justamente essas questões, e só elas, o que me encaminhou à Historia".

Em muitos casos, onde se trata de definir a posição de Ranke historiador, em face da filosofia, varia a definição segundo os seus críticos e segundo as circunstâncias. Nesse ponto ocorre o que se dá no tocante aos juizos sobre sua neutralidade ética. E significativo que, na circular dirigida aos colaboradores da História Moderna de Cambridge, confiada a sua orientação, disse-lhes Lord Acton, de modo expresso, que nada deveria transparecer nos capítulos da obra, que mostrasse a pátria, a religião, o partido dos mesmos colaboradores. Assim, a poucos anos de distância, parece abraçar aquilo mesmo que pareceu censurar no alemão, quando declara que este, em tudo quanto escreveu, tratou de reprimir em si o poeta, o religioso, o homem de partido, nada

(12). - Georg G. Iggers, "The Image of Ranke in American and German Historical Thought" History and Theory, vol. II, $\mathrm{n}^{\circ} 1$. , Haia, Mouton \& Co., 1962, pág. 18. 
publicando que afagasse os sentimentos ou revelasse os pensamentos que por ventura tivesse. Agora o que recomenda é que

\author{
"nossa Waterloo seja tal que possa contentar igualmente fran- \\ ceses e ingleses, alemães e holandeses" (13).
}

A recomendação só em parte se relaciona à conveniência, numa publicação co otiva, de manter-se a todo custo a harmonia do conjunto. Não há co.ttradição, de fato, entre ela e sua oposição à idéia da neutralidade em questões de moral, porque a moral, de seu ponto de vista, não participa do subjetivo mas representa um bem comum a toda a humanidade. Entre os $\mathbf{3 6}$ mandamentos do historiador, que anexou a uma das suas cartas a Creighton, le-se:

"No julgamento dos homens e das coisas, a Etica há de sobrepor-se ao Dogma, à Política ou à Nacionalidade" (14).

Outro era aparentemente o catecismo de Ranke, onde as opiniōes políticas ou nacionais, assim como a moral e a filosofia tinham lugar próprio e certamente ilustre, mas incompativel com o discurso histórico.

No caso dos juizos morais, a principal objeção de Ranke procede, com efeito, da crença de que tendem a introduzir uma pausa indébita no fluxo dos acontecimentos. Defendia-se, entretanto, da increpação de indiferença aos valores morais, tanto como se defendera da acusação de infenso às questões filosóficas ou religiosas, e essa atitude foi bem assinalada por um dos seus mais autorizados intérpretes (15). Em estudo de mocidade, diz com efeito Meinecke, escreveu ele, a propósito de Maquiavel, que era tempo de fazer justiça a intenções deste quando redigiu o Príncipe. Depois pareceu inquietar-se com a suspeita de que o julgariam um apologista dos princípios advogados nesse livro. E que, como excusa para tais princípios, mostrara a situação desesperadora em que se achava a Itália no século XVI, de sorte que o secretário florentino não hesitou em receitar veneno. Ao retomar o mesmo trabalho cinquenta anos mais tarde, para inclui-lo em sua obra completa, julgou Ranke de bom aviso juntar-lhe, como num aparte, a confissão de que ele pessoalmente dava tributo às "leis eternas", inseparáveis da ordem moral deste mundo, e longe estava de querer aprovar ou sequer desculpar o italiano. Não seria melhor se o incriminasse em nome das mesmas leis eternas? - pergunta Meinecke.

(13) . - Lord Acton, "Letter to the Contributors to the Cambridge Modern History", Essays in the Liberal Interpretation of Histoiy. Chicago-Lond.es. The University of Chicago Press, 1967, págs. 397 e 399.

(14). - J. E. E. D. Acton, "Acton-Creighton Correspondence", Essays on Freedom and Power. Nova Iorque. A Meridian Book, 1955, pág. 339.

(15). - Friedrich Meinecke, "Ranke", Die Idee der Staatstäson in der neueren Geschichte, Munique, R. Oldenbourg Verlag, 1957, págs. 445 e seg. 
Neste caso, porem, responde, entraria em conflito com suas idéias sobre o mister do historiador. Por isso, acrescenta, trata de dissimular o conflito, apelando para a arte elástica de seus recursos verbais. Pode-se, em suma, dizer que, nele, o discurso histórico mantem o cunho historizante, sem que o embarace o comentário do autor à margem.

Um grande historiador de nosso tempo assinalou, no entanto, a ambiguidade da fórmula do "como efetivamente aconteceu", dizendo que é característica de muitas máximas e serve para explicar sua grande repercussão. Porque, continua Marc Bloch, a idéia de que o sábio, neste caso o historiador, deve apagar-se ante os fatos, pode entender-se, por um lado, como um conselho de probidade,

$$
\begin{aligned}
& \text { "e não se pode duvidar que fosse esse o sentido que the deu } \\
& \text { Ranke", }
\end{aligned}
$$

mas alem disso é lícito interpreta-la como um convite à passividade (16) . E à pergunta sobre se é possivel ao historiador ser absolutamente imparcial, responde que a palavra "parcialidade" tambem tem duplo significado, pois pode-se ser imparcial à maneira do sábio e imparcial à maneira do juiz. Ambas as maneiras teriam suporte comum, que é a honesta sujeição à verdade. O sábio registra ou, melhor, provoca a experiência, que talvez vá deitar por terra as doutrinas que ele professa, enquanto o juiz, qualquer que seja sua íntima simpatia, só interroga as testemunhas para saber como os fatos efetivamente se deram. Até aqui não há divergência entre os caminhos do sábio e do juiz. Quando o primeiro observou e explicou, está cumprida sua missão. Ao juiz, falta porem proferir a sentença. Para isso trata de impor silêncio a suas secretas inclinações e ele se presume, assim, imparcial. Estará certo do ponto de vista dos juizes, não do prisma dos historiadores. E que, para condenar ou absolver, terá de tomar partido, abraçando uma tábua de valores que nenhuma ciência positiva tem meios de autorizar. Talvez seja possivel provar que certo indivíduo cometeu um crime, mas as civilizações não chegaram a um acordo sobre o tipo de castigo que merece o réu, de sorte que a sentença corresponde sempre a uma opinião discutivel.

Os dois caminhos assinalados por Bloch não diferem substancialmente dos caminhos descritos e separados por Leopold von Ranke: o da filosofia que, no seu entender, é o reino das leis genéricas ou abstratas, e o da História, que, partindo da observação do único, em sua unicidade, deverá entretanto explica-lo, o que só poderá fazer recor-

(16). - Marc Bloch, Apologie pour l'Histolre, ou Métier d'Historien. Paris. Librairie Armand Colin. 1949, pág. 124. 
rendo aos meios que servem para se comunicarem os homens entre si, pois que são inteligíveis geralmente. Tempo houve, segundo Bloch, em que o historiador costumava erigir-se numa espécie de juiz dos infernos, incumbindo-se de distribuir prêmios e penas aos heróis defuntos, o que supunha a existência de uma tábua de valores morais deliberadamente aceita. Contra tal posição, reporta-se ao caso das ciências da natureza, que largaram o velho antropocentrismo do bem e do mal: nenhum químico que se preze irá separar o cloro do oxigênio só porque o primeiro é um gaz mau, e o outro um gaz bom. Mas ainda que as ciências se tenham revelado mais fecundas, por mais prestativas, graças a sua "neutralidade", sabe o francês que não é lícito levar mais longe essa analogia: a História como, em regra, as ciências humanas, trata de seres naturalmente capazes de perseguir fins deliberados, ao passo que as ciências do mundo físico excluem o finalismo. A diferença reflete-se em sua nomenclatura, de modo que palavras tais como sucesso, malogro, inépcia, habilidade, que pertencem ao vocabulário corrente do historiador, assumem, no outro caso, quando muito, o papel de ficções, que só cautelosamente hão de ser usadas.

A essas precisões de Bloch pode acrescentar-se que, não raro, acontece empregarem as ciências humanas e as do mundo físico, vocábulos perfeitamente idênticos, devido à pobreza de nosso léxico, mas que, a uma análise semântica mais rigorosa, resulta terem significados profundamente diferentes. Há uma palavra que, segundo observa ainda Bloch, domina e ilumina os procedimentos do historiador, a quem hão de interessar sobretudo os seres humanos, e não as coisas físicas. E a palavra "compreender". Não se diga do historiador que é um indivíduo isento de paixões, pois que ao menos a da compreensão não lhe pode ser extranha. Note-se que a idéia da compreensão, apresentada como um instrumento cognoscitivo, diverso dos que empregam as ciências da natureza, aparecera tambem entre filósofos e historiadores empenhados em descobrir um poderoso abre-te Sésamo adequado às peculiaridades reais ou supostas das ciências do homem. As filosofias do "único" alcançaram efêmero triunfo, e se com Max Weber a idéia de "compreensão", no sentido em que foi usada por alguns neo-kantianos, teve maior longevidade foi, entre outros motivos, por ter sido associada a um método, o do "tipo ideal", que pareceu lançar uma ponte entre as tradicionais categorias das ciências da natureza e os procedimentos adotados nas ciências do homem. Ainda assim ele só passou, em geral, por uma solução plausivel enquanto não se percebeu mais claramente que escamoteava, sem supera-lo, o recurso inevitavel a generalizações. Não se pode dizer, aliás, que desapareceu hoje a auréola quase mágica que envolvera a "compreensão" entre os neo-kantianos, pois ela subsiste nas filosofias da existêmcia, embora em um caso ao menos (o de Sartre) não exclua a intelecção. 
Ranke foi historiador sem pretenções a filósofo, mas teve mais de uma vez o cuidado de definir quase filosoficamente o ofício do estudioso do passado. Entendia, ainda assim, que a história é uma ciência do único, separando-se por esse lado da fílosofia que, para ele, se ocupa de abstraçōes e generalizaçōes. Por outro lado pretende que a observação e o conhecimento do único representam só o ponto de partida do historiador. Para alçar-se ao conhecimento dos grandes nexos de sentido, faz-se necessário que siga sempre seus "próprios" caminhos, que, segundo disse, não são os caminhos do filosofo. Nesse passo, porem, seu raciocínio é pouco preciso. De fato, como ultrapassar o único, sem o que não se pode atinar com os grandes nexos de sentido a que aludiu, e evitar o genérico ou as abstrações, por pertencerem ao caminho do filósofo, se ele nega enfaticamente a existência de um terceiro caminho? O certo é que, embora alguns autores, reagindo mais tarde contra as correntes positivistas na historiografia, tentassem emancipar o conhecimento histórico das generalizações e abstrações, que passariam a ser privativas das ciências nomotéticas, e interpretassem o legado rankeano ao sabor de suas teorias, esse modo de ver já não se pode justificar hoje.

E fora de dúvida que Ranke sentiu desde muito cedo a dificuldade de estudar, pesquisar e verificar os fenômenos singulares sem o socorro de seleções, avaliações, comparações ou generalizações, e que apelou conscientemente para tais recursos. O que combatia, e expressamente, por exemplo na Conversa Política, era a crença na possibilidade de partir o historiador de teorias gerais para o conhecimento do particular. O caminho inverso, este sim, parecia-lhe possivel e necessário, se trilhado com arrojo e, ao mesmo tempo com cautela. Nas Epocas da História Moderna ele reitera essa necessidade, e ainda se refere ao erro dos que querem ver na história simplesmente um

"amontoado imenso de fatos, e acham altamente meritória a capacidade de rete-los de cor".

Daí resulta, acrescenta, que cada evento singular se segue a outro evento singular e todos são soldados entre si pela moral comum. E ainda ajunta:

"Sou mais de outra opinião, a opinião de que o saber histórico mais acabado deve ser apto a elevar-se por caminhos próprios da pesquisa e consideração do único para uma apreensão genérica dos acontecimentos e para a inteligência de suas conexões objetivas". 
Aliás o simples fato de pretender que o conhecimento do único é apenas um primeiro degrau para quem procure mostrar o passado como efetivamente foi, já exclui Ranke da escola do único, atenta só às singularidades e diferenças, mas cega às similaridades, repetiçōes e conexões. O rótulo - "escola do único" - é, segundo parece, de recente cunhagem, tendo surgido nas discussōes ultimamente suscitadas pelo interesse cada vez maior que desperta o problema da generalização em História (17). Ainda quando objetasse vivamente contra a presunção de que possa haver um sistema de leis históricas universalmente e eternamente válidas, Ranke se serviu abundantemente de generalizações para atingir ao menos àquilo a que já se chamou uma forma superior do individual (18), onde os fenômenos singulares se reorganizam em totalidades significativas. A recusa sistemática às generalizações e o aferro não menos sistemático ao único e ao não recorrente, implicariam logicamente na renúncia à nossa linguagem normal, tamanho é o número das palavras que dependem delas e que são absolutamente necessárias na comunicação de homem a homem.

Uma notavel ilustração dos métodos de Ranke, nesse particular, aparece no desenvolvimento por ele dado a sua idéia da unidade fundamental dos povos românicos e germânicos na origem de toda História Moderna, que ainda em seus dias lhe parecia guardar essa marca originária. E possivel que não fosse uma idéia nova ou inteiramente sua, e com efeito ela já aparece, em termos muito semelhantes aos que emprega, em uma carta de Guilherme de Humboldt datada de 1799 (19). Mas foi ele, de qualquer modo, quem, absorvendo-a, the insuflou vida nova e soube explora-la em todas as virtualidades numa obra extremamente fecunda. Essa idéia, "minha idéia favorita", escreverá posteriormente, já se define em seu primeiro livro, que the

(17). - Louis Gottschalk, "Categories of Historiographical Generalization", Generalization in the Writing of History. Chicago-Toronto. The University of Chicago Press, 1963, págs. 112 e segs. - A publicação dessa obra coletiva resulta de iniciativa do Committee of the Social Sciences, que incumbiu o professor Gottschalk, autor da citada comunicação, da organização de um simpósio sobre o tema. Do mesmo ano e quase com o mesmo título é outro volume - Generalizations in Historical Sciences. Philadelphia. University of Pennsylvania Press, 1963 - cujos organizadores, Alexander V. Riasonovski e Barnes Riznik, partindo do raciocínio de que é inevitavel o uso de generalizações em toda obra histórica realmente livre e criadora, argumentam (pág. 12) dizendo que é de toda conveniência o exame do procedimento intelectual de generalizar, porque um ato consceinte e refletido lhes parece melhor do que um ato irrefletido.

(18). - Theodor Schieder, Begegnungen mit der Geschichte. Göttingen. Vandenhoeck \& Ruprecht, 1962, pág. 124.

(19) . - Apud Siegried A. Kaehler, Wilhelm von Humboldt. Göttingen. Vandenhoeck \& Ruprecht, 1963, pág. 161. 
abriu as portas do professorado na Universidade de Berlim, onde trata da história dos povos latinos e germânicos entre 1494 e 1530 . Redigido quando Leopold Ranke (a partícula nobilitante ele só a terá a partir de 1865), não iniciara ainda a sistemática exploração dos arquivos; esse livro incipiente destoa, às vezes, dos critérios que passarão a presidir logo em seguida a elaboração de sua obra: não será por acaso que deixa de escrever ou publicar o segundo volume, correspondente aos anos de 1510 a 1535 , sugerido aliás, no próprio título, que será devidamente mudado 50 anos mais tarde, para incluir-se na obra completa.

Nada impede, porem, que o livro continui a ter seus devotos ainda hoje (20). O que se explica em parte pelo fato de já se acharem nitidamente formuladas em suas páginas, inclusive nas que são dedicadas, em apêndice, à crítica dos historiadores da época, os pontos de vista a que, com pouca ou nenhuma diferença, ele se manterá sempre fiel. Sem elas, especialmente sem a "idéia favorita", desapareceria o arcabouço natural de restante de sua copiosa produção. Essa presença é sensivel, depois daquele livro de 1824 , no que dedicou à história dos papas (1834-36), à da Alemanha ao tempo da Reforma (1839-1847), à do reino da Prússia (1847-49), à da França nos séculos XVI-XVIII (1852-61), à da Inglaterra, principalmente no século XIX (1859-68), e em muitos outros escritos dedicados sobretudo à Itália e à Espanha. Nem estará ausente do torso da História Mundial, que ele elaborou às pressas numa luta obstinada com o tempo, ditando a duas secretárias, (pois já meio cego não podia consultar arquivos, nem ler e escrever diretamente), mas que assim mesmo deixou incompleta quando morreu em 1886.

A idéia da unidade, até do parentesco, dos povos românicos e germânicos, prepara-se, segundo ele, no sul da Europa, como resultado das grandes migrações de povos nos séculos IV a VIII, para ir expandir-se ao norte com o império carolíngio, e é quando, a bem dizer, se forma o sentimento nacional tanto da Itália, como da França e da Alemanha, ganhando logo a Grã-Bretanha, a Espanha e a Escandinávia. Sua importância singular está em que, sobre essa idéia, descansa para ele, até na época contemporânea, toda a vida européia, alem de seus prolongamentos ultramarinos, como os do continente americano. Depois de Carlos Magno, a unidade parecerá comprometida por vários fatores, entre eles as dissenções entre o papado e os soberanos seculares, mas ressurge depois como retemperada pelas crises. Assim é

(20) . - Da História dos Povos Latinos e Germânicos escreve, por exemplo, Henri-Irenée Marrou, em "Comment Comprendre le Métier d'Historien", L'His.oire et ses Methodes, Paris, Gallimard (Encyclopédie de la Pleiade), 1961, pág. 1506: "un grand livre, consideré a juste titre comme le premier chef d'oeuvre de notre litterature, de notre science historique moderne". 
que, desmembrado o Império de Carlos Magno, a antiga unidade irá sobreviver num plano superior, sob a égide da Igreja de Roma. Tambem quando a fé religiosa deixar de ser fruto de uma adesão cândida às crenças tradicionais, para ceder às exigências de uma acquiescência bem pensada e consentida, forçando opções individuais necessariamente discrepantes, mantem-se a conexão de sentido que se situa à base de toda a moderna história. Protestantes e católicos são galhos de um só árvore, a da Cristande ocidental, separada do mundo bizantino. Depois das lutas religiosas, a unidade manifesta-se sob a forma de afeições, preceitos, instituições, códigos de compostura individual e coletiva, que, tendo raiz comum, são patrimônio de todos, de sorte que esses povos formam como uma só república.

Não importa que o historiador se dedique ao estudo das diferentes histórias nacionais, quando não perca de vista o pano de fundo que de algum modo as congrega. A história mundial, escreve Ranke no proêmio de sua última obra,

\footnotetext{
"degeneraria em fantasias e filosofemas, se quizesse deixar o terreno firme das histórias nacionais ... mas tambem não pode ancorar em definitivo nesse terreno".
}

Continuando, linhas abaixo ainda observa:

"Até mesmo da história das lutas travadas entre vários povos, pode irromper a história do mundo...".

Esse mundo, porem, deixa de ser informe ou multiforme, apenas na medida em que se organize em torno de um nexo de sentido, como o que oferece, em grau eminente, a história comum do Ocidente europeu. Sem isso, o estudioso do passado assumirá a posição de mero compilador de fatos, comportando-se passivamente diante deles. Ainda na mesma introdução à História Mundial refere-se, para rejeita-la, à tendência dos que procuram situar à base da história humana aquilo que denomina o ancestral marasmo de tal ou qual população do Oriente: é que não consegue ver como se possa acompanhar o movimento profundo e geral dessa história partindo de mundos estagnados, esclerosados ou sonolentos. A vida das nações só se faz acessivel ao historiador, segundo ele, num contexto

"onde se veja como atuaram, uma sobre outras, como se sucederam umas a outras e como, enfim, se juntaram umas com outras numa comunidade nova". 
E pois excusado querer incluir numa comunidade viva, como a dos povos da Europa ocidental, agrupamentos que lhe são heterogêneos.

O certo é que, com todas as divergências nacionais e tambem confessionais, esses povos parecem, em vários momentos bem definidos, mover-se nas mesmas trilhas, como se tivessem um só impulso a governa-los, mesmo quando pareçam separados por dissídios e rivalidades. Um desses "momentos" é o das Cruzadas, em que marcharam unidos para pelejar contra o infiel, devendo notar-se que aprofundou a divisão entre "latinos" ou "francos", como indiscriminadamente se chamavam os que seguiam a Igreja de Roma, e a Cristandade oriental ou cismática. Outro "momento" notavel há de manifestar-se depois, com a expansão ultramarina, em que diferentes nações do Ocidente europeu, guerreando-se, embora, muitas vezes, se acham articuladas pelos mesmos propósitos, nascidos da cobiça de riqueza material, do desejo de estender sobre terras distantes, muitas vezes ignoradas das gerações antecedentes, sua fé, e do empenho de dilatar alem dos oceanos a cultura que derivam de uma tradição comum. Para ir mais longe, não é muito lembrar ainda o momento da Ilustração do século XVIII, que avassalou igualmente os representantes da. Cristandade ocidental e, a bem dizer, somente esses? A origem de um tal momento ainda se discerne a presença atuante do princípio, nascido ao longo das guerras de religião, da livre adesão, de todos reconhecida, a doutrinas diversas, mas concebidas dentro do mesmo espírito cristão. Sem isso, diz Ranke no seu livro sobre a Alemanha ao tempo da Reforma, deixaria cada Estado de tolerar os direitos do vizinho, degenerando o convívio entre os povos, na prepotência de um povo sobre outros, senão numa xenofobia generalizada. Em tudo pode ver-se como o consenso sobrevive até mesmo no conflito, no caso o consenso superior da civilização do Ocidente.

O mundo das histórias nacionais de Ranke é, assim, um mundo europeu, que se dilata, sem perder o conteudo essencial, sobre províncias e continentes do ultramar colonizados por europeus. Mas não é a Europa inteira o que o ocupa, é a Europa que

\footnotetext{
"vai da extremidade do golfo de Bótnia aos promontórios mais meridionais da Sicília, e do Oder ao Adriático, às Hébridas e a Lisboa".
}

As fronteiras geográficas dessa Europa latina e germânica, protestante ou católica, são as fronteiras tambem do espaço histórico a que devotou o melhor de sua atividade intelectual. Só em raras ocasiões, e enquanto não se definiu mais sua idéia central, chegou a trans- 
po-las: quando em 1827 escreveu sobre o Império Otomano, e quando tratou, em 1829, da revolução na Sérvia. O livro sobre a Sérvia é obra de circunstância e fica à margem do resto de sua produção. $O$ outro resulta do propósito de estudar os povos do sul da Europa, de onde não lhe seria lícito expulsar os turcos. Há contudo uma explicação melhor: o lugar importante que ocupam os otomanos nas Relazioni venenezianas, que abundantemente explorou, e onde logo encontrou boa safra. Depois, o conhecimento aprofundado da história turca, uma fase singularmente fecunda da vida das nações européias, irá permitir-lhe encarar de novo prisma essa fase. Concluidas, porem, tais experiências, poderá então retomar com mais segurança os assuntos sugeridos pela sua idéia de que a comunidade romano-germânica deve erigir-se num princípio verdadeiramente axial de toda a história moderna.

Visto de nossos dias, esse princípio pode suscitar dificuldades que Ranke não considerou ou simplesmente desdenhou. Uma dessas dificuldades prende-se à operação procusteana que o leva, no descrever sua comunidade privilegiada de nações, a exclusões arbitrárias, como a da Polônia, da Hungria, até da Boêmia e Morávia, que desde o começo de sua vida histórica se prendem estreitamente a todo o complexo ocidental, ligando-se ainda a ele pela cultura e pela religião. $O$ desejo de mostrar-se coerente, não tanto as considerações históricas, forçou-o a apartar de seu sistema tão laboriosamente construido, povos que não fossem de origem românica ou germânica e, num caso particular, o dos magiares, nem sequer indo-européia. Às vezes, quando se refere a parte que puderam ter eslavos ou húngaros nos movimentos de defesa do mundo ocidental em face do perigo que representavam para ele as hordas turcas, parece, por um instante, consentir em admiti-los nesse grêmio fechado. Outras vezes, quando é impossivel negar terminantemente que eles assimilaram os valores romano-germânicos, sugere que desempenharam nesse caso um papel receptivo, mais do que ativo e verdadeiramente criador. O que é explicavel pelo fato de se situarem, e não só pela geografia, nos limites indecisos e flutuantes dos povos privilegiados.

Do ponto de vista da geografia, a explicação poderia ter algum valor para a Polônia ou a Hungria, mas não parece certa para a Boêmia que, alem de enlaçar-se intimamente, pela sua história, ao Santo Império Romano da Nação Germânica, se estende para oeste da linha que traça o Oder (com o Adriático). Referindo-se aos que ficam a leste dessa raia, mas silenciando a respeito dos que estão a oeste, há uma passagem em seu livro sobre os Estados do sul da Europa, onde alude à funda diferença existente ainda nos séculos XVI e XVII, na arte da guerra tal como a praticavam poloneses e magiares, de um 
lado, e de outro os povos germânicos e latinos. E que, enquanto aqueles conferiam realce incomparavel à cavalaria, as nações ocidentais davam preferência à infantaria e à artilharia. Assim, o rei da Polônia podia por em campo a qualquer momento uma força equestre maior do que as da Alemanha, França e Espanha juntas. No que se parecia não só com os cabos militares dos Siebenburgen e dos Szeckler da Hungria, mas tambem com o Grão-Duque de Moscóvia e os voivodas moldavos e valacos, sujeitos à Porta. A leste confinavam estes últimos, com os tártaros, que passavam a vida inteira a cavalo. Sua conclusão é de que não se tratava aqui de fenômeno fortuito, mas indício de diferenças mais fundas com as nações ocidentais, que deveriam envolver modos de pensar ou sentir e se estenderiam às formas de existência e coexistência. Parece mais facil, em suma, e mais seguro, repelir poloneses e húngaros para um mundo asiático, - alheio historicamente ao binômio Império (ocidental)-Papado, que os povos latinos e germânicos ajudaram a formar e nele deixaram seu cunho.

Quanto aos moscovitas, não constituiam problema mais sério. Parceiros tardios no concerto ocidental, onde só principiam a firmar-se em fins do século XVII, ingressaram nele por obra de um czar que, devendo impor-se a vizinhos poderosos, procurou ocidentalizar seus súditos, sem deixar de continuar um autocrata bárbaro, mais da Ásia do que da Europa. As reformas que empreendeu Pedro-o-Grande tiveram sempre em mira o bem estar de seu povo contra a cobiça alheia. Organizou uma frota, tentou criar um exército disciplinado, que o ajudariam a bater os suecos e a sustentar no trono da Polônia um candidato contrário à França e à Suécia. Perdeu para os turcos uma batalha, mas uma apenas, entre várias outras de onde se saiu vitorioso, mas pode infundir nos súditos do sultão, mormente naqueles que professavam o Cristianismo oriental, a fé no grande poder, até então ignorado, de que dispunha. Não bastava contudo esse poder para equiparar seu povo, no que respeita às artes da civilização, aos paises do Ocidente. Fundava-o, em parte, numa nacionalidade, a dos eslavos, muito mais monárquica e submissa do que a germânica, e tambem na igreja grega, tradicionalmente autocrática, mais do que qualquer outra. Se implantou no pais muito da civilização material do Ocidente, não cogitou em ocidentalizar tambem suas idéias e, acrescenta Ranke,

\footnotetext{
"nem os russos estavam aptos para tanto, de sorte que continuaram impermeáveis a todo progresso moral".
}

O mesmo, aliás, em outras palavras, já dissera em 1824, quando, depois de se referir aos vínculos existentes entre a Europa e a América, apesar da distância que separava os dois continentes, observou: 
 \\ "somos mais vizinhos de Nova Iorque e de Lima do que de Kiev e Smolensk".}

Nada melhor do que a consideração de generalizações desse tipo, que estão à base de sua historiografia, para mostrar como Ranke se encerrou desde o começo, num sistema sem desemboque, e que não mais o deixará. Fora da Europa, de sua Europa e, quando muito, fora das terras colonizadas por europeus, só existiam para ele o caos e o cemitério. Em tais condições, hão de ficar fora de horizonte que se fixou, aqueles mundos informes ou álgidos, que lhe parecem, efetivamente, terras sem história. Não querendo ser apenas um erudito, que visse na história mundial uma soma desconexa de histórias nacionais, importara-lhe principalmente discernir as grandes conexões entre os povos e verificar em que medida elas agem sobre a vida interna das nações. Em princípio nada há a dizer contra semelhante procedimento, nem parecem boas as razões dos que deploram a exiguidade do campo de visão que o leva a interessar-se unicamente por umas tantas nacionalidades. Semelhante crítica pode, aliás, com mais razão, recair sobre qualquer dos historiadores de seu tempo: sobre Macaulay, por exemplo, que só se interessa pela Grã-Bretanha, sobre Michelet que, praticamente, se ocupou apenas da França, ou mesmo sobre Burckhardt, que via unicamente, por assim dizer, os paises que orlam o Mediterrâneo e, melhor, a parte do Mediterrâneo que banha a Itália do Renascimento e Constantino-o-Grande, com a Grécia antiga.

As razões dessa crítica só valeriam, se quizessem dizer que o mundo histórico cessava, para Ranke, nos limites da Europa ocidental com seus apêndices ultramarinos. $O$ resto, não apenas deixa de interessar-lhe, mas, de fato, é como se fosse inexistente. Sua idéia do nexo de sentido, que poderia justificar-se como um princípio de economia necessário, passa a ser um mandato de exclusão sem apelo. Os povos que não tiveram o privilégio de originar-se das grandes invasões dos séculos IV a VII, que não se puzeram logo sob a égide da Igreja de Roma, que não tomaram parte direta ou indireta nos descobrimentos e conquistas ultramarinos, que nẫo se viram envolvidos, dentro do mesmo espírito cristão, mas cristão ocidental, nas guerras de religião do século XVII e nem na Ilustração do século XVIII, esses povos não tem salvação em face da História. Pouco adiantaria o terem assimilado ou o assimilarem no futuro os valores da cultura do Ocidente. Um autor moderno observou que, já no primeiro livro de Ranke, não é mencionada sequer a palavra "Ásia" como correlativo de "Europa". Quando muito há referências passageiras a algum extra-mundo ou Aussenwelt da Europa, onde vivem desvairados povos (20a). A ver

(20a) . - Apud Theodor Schieder, Begegnungen mit der Geschichte. Göttingen. Vandenhoeck \& Ruprecht, 1962, pág. 115, $\mathrm{n}^{\circ} 115$. 
dade é que em tudo quanto escreveu, e não só no primeiro livro, onde traça as linhas gerais de seu pensamento, inutilmente se procurará uma fresta por onde aquele diluviun gentium extra-europeu possa um dia ganhar ingresso em seu pantheon.

Por mais que nos possa parecer sem sentido uma concepção hierarquizada das sociedades humanas, continua ainda hoje a ser grande, e é até certo ponto justificavel, a tentação de atribuir lugar eminente àquelas que, desde o início, se identificaram com as manifestações da vida material e espiritual balizadas por noções tais como as de civilização, progresso, ciência e arte, que rapidamente se universalizam. E compreende-se que, tanto maior deva ser semelhante eurocentrismo, quanto mais se considere que a Europa, esse "cabo da Ásia", nas palavras de um poeta, se fez continente, em realidade, por causa da História, não por causa da Geografia. Considerações dessa natureza devem ter contribuido para inspirar um livro saido pouco depois da última guerra, que se intitula, aliás, História Mundial da Europa (21). O fenômeno mais perturbador de nosso século está entretanto, para Hans Freyer, o autor do livro, no fato de povos que não pertencem ao que antigamente se chamava raça brança, saberem empregar muitas das técnicas industriais mais perfeitas e, sobretudo, estarem hoje em condições de desenvolver por conta própria essas técnicas, sem ter precisado atravessar as etapas iniciais de sua elaboração e de seu progresso.

Em defesa do exclusivismo de Ranke poderia alegar-se que essa universalização da cultura ocidental parecia rigorosamente imprevisivel à época em que ele viveu, e no entanto é forçoso observar que sua noção científica da História, ao mesmo tempo em que lhe traçava limites fixos no espaço, tambem excluia a dimensão do futuro. Nada há, em sua imensa obra, que se assemelhe a certas previsões feitas por homens de seu tempo: um Heine, um Tocqueville, um Burckhardt, que seriam posteriormente realizadas. E nem há como exproba-lo por ter seguido a regra, que Hegel definiu mas não seguiu, de que não é da competência dos historiadores o arvorarem-se em profetas ou taumaturgos. A limitação de Ranke, neste particular, não está em que para ele o tempo histórico pode comportar um ontem, quando muito um hoje, cujo conhecimento nos é acessivel através de pesquisas ou de experiências, mas sem abranger o amanhã, de contornos ainda esquivos. Estaria antes em sua insensibilidade para o que possa haver de virtualidade, de promessa, de agouro no hoje, para a parte do futuro contida no pre-

(21). - Hans Freyer, Weltgeschichte Europas, 2 vols. Wiesbaden. Dieterich'sche Verlagbuchhandlung, 1948. 
sente, e naturalmente para aquele presente "gravido do futuro", da proposição bem conhecida de seu compatriota Leibnitz. Pode-se aqui lembrar ainda uma vez Hans Freyer ou, melhor, o conde Yorck, numa passagem de sua correspondência com Dilthey, que Freyer transcreve e aprova,

"Ranke", diz essa passagem, "é um grande ocular. Mesmo os preceitos críticos a que recorre, prendem-se pela natureza e origem a essa ocularidade. Quanto à matéria histórica, esta é, para ele, como um fluir de forças que vão ganhando forma. E suas personagens históricas são, a bem dizer, personae, portadoras de papeis históricos. E isso, em suma, um ver a história, não é um viver a história" (22).

A explicação não é incontestavel, e houve mesmo quem a rebatesse, mostrando o que há de verdadeiramente dinâmico-histórico nas figuras de Ranke, em contraste com o tratamento dado por Burckhardt às suas personagens que, esse sim, seria predominantemente ótico-estático (23).

Ao glosar os conceitos de Yorck, deixa entrever Hans Freyer mais uma das limitações importantes da historiografia rankeana. A "ocularidade" do historiador seria responsavel pela ênfase atribuida em seus escritos aos espetáculos mais brilhantes, mais visiveis e mais dramáticos da verdade histórica. Tudo neles, a sociedade e a economia mesmo, é encarado principalmente do ângulo político. Isto quer dizer que, alem de expulsar da história moderna as nações que não tiveram a ventura de pertencer à civilização ocidental e de professar o catolicismo ou o protestantismo, alem de dar quase como definitivo e imutavel este mundo, que deixou em 1886, Ranke vê quase sobretudo as minorias dominantes e governantes de cada pais. Um autor moderno que, não obstante, afirma e justifica a singular importância de sua obra, observa que

"o horizonte desse prussiano adotivo, desse historiador da Corte de Berlim, é como horizonte de campanário" (24),

o que não deixaria de exercer ação nefasta sobre o desenvolvimento ulterior dos estudos de História na Alemanha. São provavelmente cor-

(22). - Hans Freyer, op. cit., vol. 19, pág. 92.

(23). - Theodor Schieder, Begegnungen cit., pág. 287, nº 92.

(24) . - Fritz Wagner, Der Historiker und die Weltgeschichte. Friburgo-Munique. Verlag Karl Alber, 1965, pág. 92. 
retas as observações de Georg von Below, um mestre da História Econômica, para quem Ranke se vira forçado a dar relevo menor, em sua obra, aos problemas das instituições políticas, da economia, da literatura ou das artes, não porque se interessasse menos por esses problemas, não porque fosse mal dotado para aborda-los e, principalmente, não em obediência a algum princípio exclusivista, e sim porque, perdido numa selva selvagem de fontes documentais ainda virgens, precisou apelar para um rigoroso critério de seleção do material utilizavel, sob pena de não levar a bom termo sua obra (25). Ainda que justa, a argumentação não iustifica, ou justifica mal, o fato da divisão de trabalho que o historiador escolheu favorecer justamente os grupos politicos e sociais privilegiados.

De qualquer modo, uma crítica dessa natureza corre facilmente o risco de tornar-se anacronística, se levada às ultimas consequências, excomungando um autor simplesmente porque seguiu critérios e preferências próprios do tempo em que viveu, não do tempo em que vivemos, e que ao tratar, vamos dizer da França do grand siècle, deixou lastimavelmente de reparar que o seu personagem principal não foi bem Luís XIV e nem foi Colbert, mas foi, evidentemente, uma certa "fase B", em que a assustadora imagem da curva descendente dos preços teria servido de aguilhão para o engenho e a iniciativa dos homens, segundo se pode tirar das teorias de Simiand. A ascenção do nacionalismo burguês, que se destinaria a alterar fundamente as estruturas estatais vindas do passado, e isso não só na Alemanha, mas tambem, e mais ainda, na Inglaterra e na França, serve largamente para explicar essa preeminência do político, visivel igualmente em Macaulay ou Michelet.

E claro que há muito de inatual na historiografia rankeana e, em geral, no tipo de historismo que ele admiravelmente representou. Contudo é tão dificil renega-lo em bloco, em nome da reação contra o historismo clássico, como é dificil negar completamente a própria mentalidade historista. Pois o historismo, como já se lembrou nestas páginas, é, de fato, mais propriamente um tipo de mentalidade, não um método ou uma escola. Ernst Robert Curtius pode escrever que o

"historismo não é uma teoria científica e sim um modo de ver e de ser, surgido no universo mental de Hegel e Ranke, de Nietzsche e Jacob Burckhardt, e que só nele poderia aparecer. A Europa do Oeste permaneceu imune ao seu contágio".

(25). - Georg von Below, Die deutsche Geschichtschreibung von den Befreiungskriegen bis zu unsern Tagen. Leipzig. Verlag-Quelle E. Meyer, 1916, págs. 31 e segs. 
Em outra passagem de seu diário de leituras reitera a mesma observação e diz mais que, como forma de vivência, que atuara já sobre Goethe e Hegel, e seria ininteligivel sem Herder, o historismo é inseparavel da vida espiritual germânica (26). Curtius quer referir-se aqui, certamente, ao historismo como mentalidade e é desse que a Europa ocidental estaria livre de contágio. Porque na medida em que pode impregnar os estudos históricos, dando-lhe rumos novos e mostrando sua alta eficácia, é inegavel que pode encontrar larga acolhida nos paises do oeste da Europa e ainda na América do Norte. $O$ autor de um estudo sobre a poderosa influência da "escola histórica alemã" na Inglaterra (27), teve o cuidado de frizar, logo de início, que foi principalmente no campo restrito dos estudos históricos, no modo de encarar a história, que ele teve na Inglaterra a "enorme influência" descrita no seu livro e confirmada no prefácio de G. P. Gooch.

A idéia que sustenta Curtius, de uma radical incompatibilidade de franceses e ingleses com a forma mentis especificamente alemã representada pelo historismo, faz pensar na distinção e antagonismo entre "cultura" e "civilização", que andou em moda na Alemanha guilhermina. Seja como for parece desnecessário admiti-la para acreditar que não seria facil ao pensamento germânico despojar-se de uma tradição inveterada e extremamente rica. As críticas de Hans Freyer, por exemplo, ao chamado quietismo de Ranke, onde se pretende ver substituida uma historiografia inerte por "atos de decisão" e "tomadas de posição", não se situam forçosamente fora da órbita do historismo. E menos ainda o apelo de Erich Rothaker em favor da enérgica afirmação da responsabilidade - contra certas doutrinas fatalistas (Spengler por exemplo) - , onde recorre generosamente a palavras tais como honra, heroismo, luta, orgulho nacional (28). Embora, por ocasião da famosa "querela dos métodos" (Methodenstreit), de 1896-7, tivesse estado mais perto de Lamprecht, com suas tendências vagamente positivistas, Rothaker voltou depois à tradição idealista germânica. E possivel talvez vislumbrar alguma afinidade entre o pensamento de Freyer e Rothaker e a teoria que já em 1919 defendera Theodor Lessing, ao insurgir-se contra uma historiografia que postula

"com segurança fofa: assim foi!"

(26). - Ernst Robert Curtius, Büchertagebuch. Berna e Munique. Francke Verlag, 1960, págs. 31 e 99.

(27). - Klaus Dockhorn, Der Deutsche Historismus in England, Göttingen, Vandenhoeck \& Ruprecht, 1950, págs. 133 seg.

(28). - Erich Rothaker, Geschichtphilosophie. Hamburgo. Hanseatische - Verlagsanstalt, 1936, pág. 134, e Logik und Systematik der Geisteswissenschaften. Bonn. H. Bouvier u. Co. Verlag, 1948, págs. 168 e seg. 
em vez de dizer orgulhosamente e de consciência limpa:

"assim deve ter sido!" (29).

O que ele pretendia, em suma, resume-se numa sentença que, para ser melhor traduzida, reclama a criação de um neologismo: a História, diz, não é ciência (Wissenschaft), é "volência" (Willenschaft) transformadora.

Theodor Lessing já se colocava abertamente no polo oposto a Ranke e mesmo às diferentes modalidades do historismo. Outro tanto ocorre com as posições radicais de alguns autores de influência bem mais ampla do que a sua e que, cada um a seu modo, negam todo e qualquer significado ou valor objetivo à história e à ética. E esse o caso, principalmente, de Martin Heidegger com sua filosofia da Existência, do jurista Carl Schmitt, que definiu um conceito de política alheio aos valores éticos universais e à racionalidade, fundando-o essencialmente na antinomia amigo-inimigo, e tambem do ensaista e novelista Ernst Jünger, cuja mensagem intelectual foi definida na fórmula

$$
\text { "niilismo heróico" (30). }
$$

Em estudo recentemente dedicado ao problema da dissolução do historismo, chegou-se a dizer que, com o "decisionismo" desses últimos autores, atinge sua conclusão lógica o relativismo historista, que é negado, por sua vez, pela noção heideggeriana de historicidade (31). Tambem o sociólogo A. von Martin situa-a na linha do historismo ou mais precisamente do próprio Ranke e de sua teoria das idéias, Ranke só reconheceria idéias históricas, "no tempo", rejeitando como abstratas as idéias puras, permanentes, objetivas e absolutas, metafísicas e éticas (32). Os herdeiros, porem, do historismo clássico se inclinariam a repelir essa filiação suposta para o lado dos descaminhos do saber histórico.

A linguagem de alguns desses autores aparenta-se, não raro, à dos teóricos do nacional-socialismo. E se é certo que Th. Lessing

(29). - Apud Theodor Litt, Wege und Irrwege Geschichtlichen Denken. Munique. R. Piper \& Co. Verlag, 1948, pág. 91.

(30) . - Alfred von Martin, Der heroische Nihilismus und seine Uberwindung. Krefeld. Scherbe Verlag, 1948.

(31). - Georg G. Iggers, "The Dissolution of German Historism", Richard Herr e Harold T. Parker (eds.), Ideas in History: Essays presented to Louis Gottschalk, Durham, Duke University Press, 1965, pág. 108.

(32). - Alfred von Martin, op. cit., pág. 82. 
mostrava tendências esquerdizantes, e suicidou-se em 1933, o ano da ascenção de Hitler, não só Heidegger, Schmitt e Jünger, como tambem Freyer e Rothaker, aprovaram, ao menos temporariamente, o advento do $3^{\circ}$ Reich. E significativo que todos, salvo Rothaker, tinham superado a posição historista. Com o nazismo triunfante, essa posição pareceu na iminência de desmoronar-se, mas já antes a ameaça começara a ser pressentida. Em 1930, numa conferência pronunciada no congresso internacional de filosofia reunido em Oxford, Benedetto Croce, representante na Itália do historismo racionalizante de Hegel, chamava atenção para uma campanha generalizada que, a seu ver, se desenvolvia contra a idéia historista. Essa campanha, que ele associava à crise do liberalismo, responsavel pela instalação em vários paises de regimes autoritários, parecia-lhe sinal de empobrecimento mental, de debilidade moral, eretismo, desespero e neurose (33). Pouco depois, em 1932, publica Karl Heussi um livro de certa reperecussão na época, onde trata expressamente da "crise do historismo". Em resenhas que publicou sobre os escritos de Croce e Heussi, reafirma Meinecke sua convicção de que o historismo é das mais altas e mais genuinamente germânicas contribuições do espírito alemão.

Apesar de sua formação monárquica e bismarckiana, Meinecke aceitara como irremediáveis as transformaçóes internas de seu pais depois da derrota de 1918. Tornou-se republicano e, por filiação partidária, democrata, mas republicano e democrata de razão. Batera-se mesmo por um regime que fosse como um sucedâneo, um Ersatz, da monarquia, segundo ele mesmo escreve em suas reminiscências (34), e onde não houvesse lugar para um parlamentarismo inglês ou francês. Optava antes por um sistema semelhante ao dos Estados Unidos: presidencialista de cunho acentuadamente plebiscitário. Essa aspiração, partilhada tambem por Neumann e Max Weber, teve algum eco na constituição de Weimar. Entretanto, com a ordem nova que instaura o Terceiro Reich, ele, o historiador do historismo, jamais se conformará, e o preceito rankeano do "como efetivamente aconteceu" vai mudar-se numa pergunta: "como pôde acontecer?" Procura um pobre consolo na idéia de que o fenômeno hitlerista seria mais europeu do que propriamente alemão, embora em 1934 ainda registrasse, aprovando-a, a observação de Croce, de que a Inglaterra e a França ficaram imunes à crise do liberalismo (35).

(33). - Benedetto Croce, Punti di Orientamento della Filosofia Moderna - Antistoricismo, Bari, Laterza \& Figli, 1931, pág. 33.

(34). - Friedrich Meinecke, Erlebtes: 1862-1919 Stuttgart. K. F. Koehler Verlag, 1964, págs. 331-2 e 341-2.

(35). - Friedrich Meinecke, Zur Theorie und Philosophie der Geschichte. Stuttgart. K. F. Koehler Verlag, 1959, págs. 196-211. 
Dez anos depois da ascenção de Hitler, já em plena guerra, a seu antigo discípulo Siegfried Kähler escreveu que se ia ocupando cada vez mais com a obra de Burckhardt, cuia importância crescia a seus olhos, e perguntava-se mesmo se, ao termo da crise européia e mundial, não acabaria por fazer triunfar o mestre de Basiléia, sobre o próprio Ranke. Logo emendou porem: não seria com certeza uma vitória completa, mas - quem sabe? - uma boa vitória parcial. Ao mesmo Kähler mandará dizer mais de um ano depois, em setembro de 1944, que já começava a sentir-se mais longe de Ranke e mais perto de Burckhardt. Em 1947 podia escrever, dessa vez a Spranger, que Burckhardt, graças ao seu pessimismo, conseguira mergulhar fundo nos desvãos escuros da história, tornando-se um profeta de desgraças, ao passo que Ranke, sempre confiante no "sopro divino", ficara preso àquele "oasis humanitário" do século XIX, que agora mostrava sua face real: "Fata Morgana maravilhosa, mas mentirosa". Aquele bom mundo europeu de Ranke revelava agora sua fragilidade. Pareceu-lhe isso bem claro quando viu aproximar-se o fim da guerra: "os ataques de americanos e russos à velha Europa apresentam-se", dizia,

\footnotetext{
"como uma espécie de parricídio civilizatório. Dois povos dos quais mal se pode dizer que existiam há 200 anos, que são o que hoje são graças a europeus e a exemplos europeus, ultrapassam agora a Europa na técnica da destruição e no uso frio da "razão" calculada para destruir" (36).
}

Finalmente em 1948 publica Meinecke seu estudo tantas vezes anunciado sobre Ranke e Burckhardt (37). Passada agora a borrasca, iá não dá entretanto vitória nem meia-vitória à voz de Cassandra . No confronto quase se equiparam o mestre de Berlim e o mestre de Basiléia, talvez com pequena vantagem para o primeiro. Ranke não deixara de assinalar a importância dos grandes momentos regeneradores no passado, enquando a visão mais predominantemente estética do suiço não lhe permitia dar a devida atenção a tais momentos. E lícito perguntar mesmo se o profeta de catástrofes não seria sobretudo um professor de desalentos, que fecha os caminhos do futuro. Burckhardt é autor de uma frase célebre, a de que "o poder é intrinsicamente mau", e sabe-se hoje que ele jamais conseguiu retribuir sem reservas a constante amizade e admiração que lhe tributava a um colega seu, Frederico Nietzsche, da Universidade de Basiléia, depois convertido,

(36). - Friedrich Meinecke, Ausgewählter Briefwechsel. Stuttgart. F. K. Koehler Verlag, 1962, págs. 277, 279, 421, 468, 259.

(37). - Friedrich Meineck, Zur Geschichte der Gechichtsschreibung. Munique. R. Oldenbourg Verlag, 1968, págs. 93 a 121. 
mal ou bem, em nume tutelar do nazismo (38). Era notória a desconfiança com que encarou a obra de Bismarck, embora admitisse que o chanceler prussiano tentou fazer uma revolução que algum dia devia rebentar sem ele e contra ele. Mas até onde seria bem sucedido o projeto reformador? Burckhardt era mais resolutamente conservador do que Ranke. Tambem este tinha medo de reformas, até de reformas vindas de cima, e no entanto silenciava sobre suas divergências, e seria capaz, em último caso, de aceitar uma situação verdadeiramente revolucionária. Por oportunismo e tibieza de convicções? Que benefício tiraria Meinecke, o Meinecke já octogenário, de trocar pelo historismo de Burckhardt o historismo de Ranke? Ocasiões houve em que foi ao ponto de descrer de seus venerandos mestres. Em carta de 1946 ao historiador austríaco Srbik, escrevia:

"Como destoa o espetáculo que hoje assistimos daqueles quadros que nos legaram Ranke, Treitschke, Burckhardt sobre a Alemanha e a Europa! Nenhum dos três, com efeito, nos satisfaz completamente. Não. Nem mesmo Burckhardt, o clarividente, pois ele só via trevas em nosso destino... e no entanto tivemos tambem horas sadias e gratas ao longo da história".

No mesmo ano de 46 perguntou certa vez a um conhecido seu norte-americano, ocupado segundo dizia em atrair mestres que não tivessem tendências reacionárias para a Universidade de Munique, se achava que, na Alemanha, o número de indivíduos sérios, de carater firme e merecedores de confiança fosse menor do que em outros paises. "Acho!", retrucou-lhe brutalmente o outro. Muito antes, durante a primeira guerra mundial, quando de todas as partes do mundo partiam clamores contra as "truculências" alemãs, começou Meinecke a redigir seu livro sobre a razão de Estado. E uma obra objetiva e sem finalidades polêmicas, mas onde se mostra como a vontade de poder a todo transe, exercida sem escrúpulos, nasceu e se desenvolveu fora da Alemanha. E embora a parte final do livro seja dedicada aos representantes germânicos da doutrina, a verdade é que eles constituem reduzida minoria. Diante, porem, da opinião generalizada no estrangeiro de que o hitlerismo se enquadrava bem na tradição germânica, e com ela se confundia, achava necessário um exame de consciência.

Agora, quando recebia da Inglaterra uma carta de Gooch onde se falava em "Ranke, o mestre de todos nós", e se exaltava uma obra recente sobre Frederico-o-Grande, escreve que manifestações como

(38). - Ver sobre as relações entre Nietzsche e Burckhardt, Alfred v. Martin, Nietzsche und Buickhardt. Basiléia. Ernst Reinhardt Verlag AG., 1945. 
essa parecem particularmente oportunas num momento em que se faz necessário defender os valores tão universalmente combatidos da história alemã, mas insiste na necessidade de uma revisão meticulosa desses valores. Ao amigo Spranger faz mesmo esta confissão:

"Frederico-o-Grande e Bismarck não foram apenas construtores, mas tambem destruiram muita coisa, e a construção do Estado prussiano-alemão foi uma tremenda tragédia, e não aquele espetaculo harmonioso em que nos comprazíamos tanto" (39).

Entre as revisões que já lhe pareciam inevitáveis, não hesita mesmo em situar a do historismo clássico. Punha agora em dúvida, especialmente, a tese da bondade do relativismo histórico e da neutralidade ética, inseparáveis da "escola histórica alemã", de que tinha sido até pouco antes um intransigente campeão.

Em 1932, ao fazer a resenha do livro de Heussi sobre a "crise do historismo", já consentira em admitir que o relativismo tem dois gumes, mas ainda achava que, por si só, não é necessariamente nocivo, e que no sentido que ele próprio lhe dava, não era contestavel. Em 1950, um jovem historiador suiço, em livro de mais de quinhentas páginas em torno da obra de Meinecke, mencionava e aprovava a idéia de que os valores históricos não podem ser procurados em nenhum sistema absolutista: relatividade e imanência tomam o lugar do absoluto e da transcendência (40). Assim pensara sempre o próprio Meinecke, mas dessa vez, na carta em que agradece ao autor do estudo a interpretação geralmente correta que dá de sua obra, observa que os abalos padecidos numa idade avançada trouxeram à tona para ele dois problemas de suma importância. Perguntava, primeiro, se seria possivel, com o princípio da relatividade, chegar a uma crença firme e consciente no absoluto e no eterno. A segunda duvida era sobre o Estado Nacional fundado na força. Como insistir nele quando se vê seu total desmoronamento, e sobretudo, o que pensar das relações dessa idéia com o Estado prussiano-alemão e sua história?

Meinecke fazia questão de frizar que, ao afirmar a necessidade teórica e prática da aceitação de um princípio absoluto e perene, ele não se considerava um renegado. $O$ que esperava era uma resposta por onde os valores antigos fossem suspensos-abolidos (aufgehoben)

(39). - Friedrich Meinecke, Ausgewälter Briefwechsel. cit., págs. 259, $596,593$.

(40). - Walther Hofer, Geschichtschreibung und Weltanschauung: Betrach tungen zum Werk Friedrich Meinecke. Munique. Verlag von R. Oldenbourg, 1950, págs. 287 e segs. 
na nova forma de existência dos povos ocidentais (41). O clima trágico dos anos do Terceiro Reich, da guerra, do após-guerra, não se compadecia com o otimismo sossegado que o pensamento rankeano tendia a infundir. Significativo desse tipo de reação é um dito atribuido ao historiador Peter Rassow:

"Já basta de história alemã! Passemos à história européia!".

A tanto chegou esse estado de espírito, que um outro historiador, Gerhard Ritter, que conspirou ativamente contra o hitlerismo, que escapou de morrer na prisão por esse motivo, e que escreveria a biografia de Carl Goerdeler, a figura central da resistência civil alemã, executado a 2 de fevereiro de 1945, lamentava agora que, depois de um endeusar frenético de tudo quanto fosse alemão se passasse a sistematicamente denegrir todos os valores germânicos. E era inevitavel que, no seu auge, essa reação fosse atingir até a "escola histórica", tanto mais quanto, apesar de excepções como a de Gooch, não a poupavam vozes estrangeiras ilustres. Em 1950, escrevendo a Srbik, queixava-se Meinecke da triste sina do "pobre historismo", atacado agora de todos os lados. Nem o poupavam, na Itália, discípulos de Croce, e até o chefe da igreja católica se volvia contra ela.

Com efeito, em livro que acabava de sair em tradução alemã dizia Carlo Antoni, por exemplo, que o historismo anti-racional e anti-mecanicista chegaria a um pluralismo negador dos valores universais e, em suma, à dissolução da fé no próprio pensamento (42). Embora o escritor ressalvasse expressamente a posição do velho Meinecke, sem dúvida porque, mesmo sem filiar-se à corrente hegeliana, tal como a representou Croce, cabia-lhe mal a etiqueta de anti-racional, não via este tranquilamente a ofensiva generalizada contra os princípios que julgou bem esposar. E a esse coro de apóstrofes não vinha juntar-se a encíclica Humani generis de 12 de agosto de 1950, onde são criticados os efeitos do falsus quidam historicismus? Cinco meses mais tarde, escrevendo ainda a Srbik, pergunta Meinecke:

"Com o historismo sustenta-se ou decai a natureza humana?"

E ele mesmo responde:

"Parece-me que caminhamos agora para uma síntese nova do historismo com o Direito Natural".

(41). - Friedrich Meinecke, Ausgewählte Briefwechsel, cit., pág. 256.

(42) . - Carlo Antoni, Dello Storicismo alla Sociologia. Florença G. C. Sansoni, 1951, pág. 120 e passim. 
Contudo à intensidade das críticas feitas à "escola histórica" começavam a corresponder, tambem no estrangeiro, reações que a favoreciam. As palavras de Gooch sobre "Ranke, o mestre de todos nós" já não representavam opinião isolada. O frances Raymond Aron dizia:

"o relativismo, que a própria história da ciência histórica justifica, não parece tender a destruir a história científica, desde que corretamente interpretado".

Por sua vez o norte-americano Alan Bullock, em artigo publicado em 1951 em History Today, defende a idéia de que a História não foi feita para suportar o peso dos sistemas de absolutismo moral. Finalmente Geoffrey Barraclough, inglês e professor em Cambridge como Gooch, poderá dizer em 1956, a propósito do historismo:

"Nenhum de nós, quaisquer que sejam nossos interesses particulares, pode fugir hoje ao seu influxo envolvente" (43).

Apesar de tudo, um número crescente de alemães, desarvorados ainda pela catástrofe nacional, continuava a voltar-se contra o que Meinecke chegara a denominar outrora
"a maior revolução que produziu o pensamento alemão depois da Reforma".

Uma das ofensivas mais radicais que se fizeram, não só contra o historismo alemão, mas contra a historiografia moderna de um modo geral, partira em 1948 de um emigrado que, fugindo à perseguição nazista, correra diversos paises da Europa e da Ásia, até fixar-se nos Estados Unidos. Publicado primeiramente em inglês, o livro de Karl Löwith só sairia em 1954 em alemão com o título de História Mundial e História Sagrada, e logo alcançou desusada repercussão. Num resumo superficial da argumentação desse antigo discípulo de Huserl, pode-se dizer que seu núcleo está na idéia de que o princípio judeu-cristão de uma providência divina a dirigir o destino dos povos não distingue só a historiografia que se estende desde Santo Agostinho até Bossuet, mas continua a existir, dissimulado, depois que à providência divina se substituiu a providência humana. Em outras palavras, o providencialismo velho viu-se substituido por um novo providencialismo, um providencialismo secularizado. E não é por acaso, observa Löwith,

(43). - Hans Meyerhoff, The Philosophy of History in Our Times. Nova Iorque. Doubleday Anchor Books, 1959, págs. 29, 159 e 298. 
que em nossa linguagem ordinária, palavras tais como "sentido" e "fim", "sentido" e "destino", são intercambiáveis.

Acompanhando toda historiografia desde Orósio e Agostinho até a metahistória de Spengler e Toynbee, ou melhor, partindo destes para aqueles, o que the parece predominar, com poucas exceções, é o fundo escatológico ou, de qualquer forma, teleológico. Em Voltaire, por exemplo, é a religião ou a irreligião do Progresso o que dirige toda a História, fundadas na crença de que podemos aperfeiçoar constantemente nossas condições terrenas sem ser necessário esperar o advento do Reino de Deus, que se opõe à Cidade dos Homens. Em Hegel outro exemplo entre muitos - a filosofia mostra, ao contemplar a História, que a razão preside o curso de todos os acontecimentos terrenos. E esse pensamento simplifica-se, observa o autor, se o processo histórico seguir, como em Hegel, o modelo iniciado com a idéia da realização futura do Reino de Deus, e a filosofia da história for concebida à imagem de uma Teodicéia. Até a "astúcia da razão" hegeliana não é senão uma racionalização do conceito de Providência. Por sua vez, o próprio Burckhardt, que tanto se irritava com a idéia da racionalidade universal, faz assentar todo o processo histórico no princípio da continuidade. $O$ significado verdadeiro desse princípio estaria, segundo Löwith, em que o legado da História há de ser preservado da ameaça revolucionária. Para Burckhardt não é a formação liberal ou o progresso material o que salvará a alma humana, e sim a religião, porque só mesmo um apelo ao transcendental, capaz de sobrepor-se ao vozerio dos que demandam o poder ou a pecúnia, pode ser de algum proveito para a humanidade.

Em contraste com esses historiadores que prolongam ou substituem, sem muda-lo no essencial, o pensamento substancialmente futurista do Velho e do Novo Testamento, os historiadores e filósofos da Antiguidade clássica são alheios, segundo a interpretação de Löwith, ao princípio da continuidade na história (44). Na posição daqueles que professam hoje esse princípio da continuidade ele discerne uma funda inconsequência. Para serem consequentes seria preciso que voltassem à teoria do movimento circular, visivel até na obra de Políbio, por mais que as descrições deste pareçam ter um escopo definido no império universal de Roma. Em verdade não é possivel pensar a História como processo contínuo, sob a forma de um progresso recti-

(44). - Karl Löwith, Weltgeschichte und Heilgeschichte. Zurique-Viena. Europa Verlag, 1954. O mesmo tema é tratado resumidamente por Lïwith em Anteile: Maitin Heidegger zum 60 Geburtstag. Francforte-sobre-o-Meno. Vittorio Klostermann, 1950, págs. 106-153, e em Leonhard Reinisch (dir.), Der Sinn der Geschichte. Munique. Verlag C. H. Beck, 1961, págs. 31 a 49. 
líneo a que faltam o terminus a quo e ad quem, isto é, que não tenha começo nem fim. A solução que oferece o pensamento histórico fertilizado pelo princípio judeu-cristão da Providência, e mais tarde secularizado, não deixa de ser equívoca. Arredou-se dele o que pertencia à herança cristã, como sejam a idéia da Criação e a da Consumação, para inserir elementos pertencentes à tradição greco-romana, mas sem adotar, neste caso, a estrutura cíclica. O espírito moderno parece indeciso sobre se há de pensar à maneira cristã ou à maneira pagã, de sorte que vê o mundo com dois olhos diferentes, o da fé e o da razão, e o resultado há de ser, por força, uma visão turva.

A contribuição de Löwith merece ser referida numa resenha sumária das tendências do pensamento histórico alemão dos últimos tempos, pela luz que jorra sobre alguns problemas que, abertamente ou não, vinham ocupando esse pensamento. E o que parece explicar em parte o interesse por ela suscitado geralmente, e não só nos círculos mais doutos. Interesse que nem sempre significou, aliás, adesão: é compreensivel, por exemplo, a repercussão desfavoravel que teve entre alguns marxistas da vertente hegeliana, como é o caso de Ernst Bloch e de Jürgen Habermas. Mas ainda que se dê de barato a alegação feita de que o feliz êxito dessa e de outras obras de Löwith é devido, ao menos em parte, à vasta campanha de publicidade que antecedeu e sucedeu ao seu lançamento (45), é inegavel que a singeleza das fórmulas que utiliza para explicar todo um vasto conjunto de fenômenos naturalmente complexos, ajudou em grande parte essa acolhida, sem falar na felicidade com que pôs vários daqueles problemas. Nem é de desprezar o apelo exercido, muitas vezes, no mundo moderno, particularmente na Alemanha moderna, pela nostalgia e até pela fetichização das origens, que é como o reverso obrigatório do desejo de desmascarar e "passar a limpo" os fundamentos de nossa civilização. Por esse lado, alguns dos conceitos do antigo emigrado, e quase vítima, do nazismo, têm por onde comparar-se com os de Heidegger, quando reabilita o pensamento pré-socrático, ou mesmo com os de Ludwig Klages, que quis recuperar o mundo pré-helênico dos pelasgos, ou pré-romano dos etruscos, e que, mais ainda do que Spengler, se achava no vestíbulo do Terceiro Reich.

Contudo o que nos interessa aqui é o fato de sua obra ter podido aguçar a sensibilidade dos historiadores para algumas questões que, desde há algum tempo, pareciam querer vir à tona. Isso diz respeito particularmente a duas idéias: a do sentido (e fim) da História e a da discontinuidade. São questões, essas, que vem interessando cada vez

(45). - Jürgen Habermas, Philosophisch-politische Profile. Francfortesobre-o-Meno. Suhrkamp Verlag, 1971, pág. 116. 
mais os historiadores, não apenas na Alemanha. E o interesse suscitado independentemente, em vários paises, por essas questões, sugere que a historiografia germânica tende a deixar aquela espécie de "explêndido isolamento" a que se teria confinado nos tempos áureos do historismo. Assinalar o mérito de Löwith ao enfocar tais problemas, não significa endossar sempre o desenvolvimento genético engenhoso e sedutor que ele propõe. Em alguns pontos seus argumentos são discutíveis e, de fato, já têm sido discutidos, como no caso da diferença que estabelece entre o conceito pagão de tempo, com seu curso cíclico, e o judaico-cristão, que introduziria a idéia do movimento retilíneo, a mesma que se encontra, secularizada embora, entre modernos historiadores. A isso retrucou um teólogo, Hans Urs von Baltasar, que o tempo bíblico e cristão tem tambem curso circular: do Criador procede o homem, que dele se aparta com a Queda, mas a Ele há de voltar pela expiação ou redenção. Essa contestação, que seria desenvolvida em estudo mais amplo, figura no resultado de um inquérito sobre o "sentido da História" (46), onde colaborou igualmente o próprio Löwith, alem de Golo Mann, Rudolph Bultmann, Litt, Toynbee e Popper.

Em realidade ela diz respeito, não à idéia do tempo retilíneo dos historiadores, que sua presença entre eles não sofre contestação, mas que poderia ter outra origem, mas sim à contrução genealógica de Löwith. Segundo Baltasar, a noção ou, como ele diz, a "ilusão" do tempo histórico retilíneo, emergiu das ciências naturais, deixando-se logo dominar pelas "antinomias da razão pura", pois como seria possivel supor, pergunta, que ele fosse afinal desaguar na Divina Eternidade? (47). Independentemente de qualquer explicação escatológica, essa preocupação com o sentido (fim) da História, está longe de ser uma especialidade alemã. Atesta-o o prestígio alcançado em toda parte pela historiografia preditiva (ou profética) denunciada por Popper e pelos "racionalistas críticos" (que, como ele, repudiam o rótulo de neo-positivistas), sob o nome de historicismo. E bom repetir que esse "historicismo" nada tem de comum com o historismo de que tratam estas páginas, e abrange não apenas o pensamento de Hegel ou Marx, mas tambem o positivismo de Comte e Stuart Mill, cujas raizes estariam no jusnaturalismo da Ilustração, contra o qual reagiu o historismo.

Nos nossos dias, um exemplo notavel desse tipo de historiografia que Popper denuncia é o de Arnold J. Toynbee, onde as várias "civilizações" são tributárias, entre outras, da regra universal do "repto

(46). - Leonhard Reinisch (dir.), Der Sinn der Geschichte. Verlag C. H. Beck. Munique, 1961.

(47). - Idem, págs. 118-9. 
e réplica" (challenge and response), que mostra como devem nascer, devem crescer e podem parecer as mesma civilizações. Podem e não devem perecer, porque, havendo uma réplica à altura do repto, ainda terão meios de recuperação, e é principalmente neste ponto que Toynbee se distingue de Spengler. Isso não impede, porem, que a grande maioria das suas "civilizações" tivesse afinal perecido. Até a nossa, do Ocidente, deixa entrever para ele sinais de declínio desde o século XVI, de maneira que é previsivel seu colapso, de que só escapará milagrosamente, pela retroconversão geral às crenças de nossos antepassados. E um grande número das respostas aos críticos de seu sistema, que ele compendia no $12^{\circ}$ volume da obra, poderiam resumir-se nas palavras com que, em 1948, retrucou em programa da B. B. C. de Londres às arguições do historiador holandês Peter Geyl:

\footnotetext{
"Essa missão de dar sentido à História é das mais clamorosas necessidades de nosso tempo. Creia no que lhe digo!" (48).
}

No caso de Ranke dá-se exatamente o oposto. Uma das constantes críticas que ainda em vida dele lhe foram feitas dirige-se contra sua recusa deliberada a querer dar um sentido à História. Não será por acaso que, entre os autores citados por Löwith para ilustrar sua tese da secularização da escatologia judaico-cristã, ou seja do carater teleológico do pensamento histórico depois de Vico e Voltaire, nem uma vez aparece o seu nome. Em realidade a obra de Ranke não poderia exemplificar amplamente essa tese ou, quando muito, seria um mau exemplo, ainda que, de certo modo, corresponda à explicação do historismo como uma espécie de absolutismo do relativo. Na introdução à História Mundial é ele próprio quem diz que,

"pretender dar-lhe (à História) um sentido e fim determinado (...) é ignorar as ilimitadas projeçóes da História universal".

E se a ausência do raciocínio teleológico for virtude, o defeito que põe Freyer na historiografia rankeana, a que chama sua "cegueira para o futuro", seria o defeito da mesma virtude. E forçoso, a propósito, citar ainda uma vez Meinecke, um dos intérpretes mais autorizados dessa historiografia, que mal se conforma, entretanto, com a idéia de que seu mestre não admite a ação da Providência na História. Ranke acreditava com certeza em um providencialismo, observa, mas julgava

(48). - Can We Know the Pattern of the Past? - Discussion between Peter Geyl, Professor in the University of Utrecht, and Arnold J. Toynbee, Professor in the University of London concerning Toynbee's Book A Study of History. Bussum. Holanda. Uitgeverij F. G. Kroonder, 1948, pág. 30. 
que sua presença foge ao exame empírico, mesmo aturado. Seria, a sua, uma teleologia que se dissimula ou, para recorrer a palavras de Gerhard Mansur, outro intérprete da historiografia rankeana, uma teleologia sem telos (49). Dificilmente se explicaria, porem, como uma teleologia inacessivel ao estudioso de História pudesse afetar-lhe o raciocínio.

Em todo caso, na primeira palestra ou, como dizia na primeira, "rapsódia", do curso dado no outono de 1854 em Berchtesgaden, Ranke declarou expressamente que não há como sustentar de um ponto de vista filosófico, e nem demonstrar do ponto de vista histórico, a crença em uma vontade geral que dirigiria o desenvolvimento do gênero humano de uma a outra etapa, ou em uma espécie de empuxe espiritual que levasse a humanidade forçosamente a um fim determinado. E na mesma palestra inicial, como lhe perguntasse o rei Max se julgava inadmissivel a opinião de que a Providência, sem prejuizo do livre arbítrio individual, fixou certo fim para a humanidade em conjunto, ao qual ela seria conduzida, embora não a força, a resposta foi:

"E essa uma hipótese cosmopolita, porem não há meios de prova-la com argumentos tomados à História. E certo que, segundo as Sagradas Escrituras, dia virá em que teremos um só pastor para um só rebanho, mas nada indicou até aqui que o caminho dominante na história mundial esteja nessa direção" (50).

Ao lado do problema do sentido (fim) da História, outra idéia, que se vem impondo cada vez mais a historiadores de vários paises, a da continuidade-descontinuidade, tambem encontra solo de eleição na Alemanha. Uma das explicações plausíveis para esse fato oferece-a o medievalista Hermann Heimpel em vários escritos, especialmente em comunicação oferecida em 1957 à 23a Conferência Anual de Historiadores Alemães.

"Nos últimos dez anos", disse, "o sentimento de culpa e o destino, transformaram-nos em um povo sem História. $E$ isso há de perdurar enquanto não se erigir em nossa consciência uma

(49). - Friedrich Meinecke, Zur Theorie und Philosophie der Geschichte - cit.. págs. 130 e seg.

(50): - Usou-se aqui o texto da recente edição crítica das Epocas, organizada por Theodor Schieder e Helmut Berding (Leopold von Ranke, Uber die Epochen der Neueren Geschichte. Munique-Viena. R. Oldenbourg Verlag, 1971 , págs. 54 e 71), baseada sobretudo no manuscrito que pertenceu ao rei Maximiliano II da Baviera, e que melhora o da edição de Alfred Dove, impressa após a morte de Ranke, em 1888, em anexo aos fragmentos da História Mundial. 
ponte entre 1933 e 1945, enquanto tivermos de encarar aquele tempo como se tivéssemos sofrido então uma queda e, em suma, como se o não tivéssemos vivido, como se não o devêssemos inserir na continuidade de nossa História. De nada adiantam, contra - lançamento dessa ponte, argumentações metodológicas que possam desfavorecer a história de hoje. Sem história atual, já não nos poderíamos dedicar à história mais antiga, e o pior tipo de ausência de História é aquele que se entretem em impensadas restaurações. Estas acbariam por tirar sua autonomia à ciência da História, e cairiam no jogo das ações e reações: germanomania, germanofobia..." (51).

A seguir o autor se refere a um generalizado taedium historiae, que pede a revisão, hoje, de nossos conceitos históricos e tambem faz algumas reivindicações que lembram as tentativas oitocentistas de racionalização da História, expressas, não só na teoria marxista, como nas concepções de Comte e de Lamprecht. Essas reivindicações tendem a universalizar-se segundo Heimpel, que alude aqui ao grupo francês dos Annales.

Não é provavelmente exagerada a idéia de que o sentimento, inconsciente ou cultivado, de que há uma fratura na vida alemã do período que vai de 1933 a 1945 , ajudasse a desvalorizar o princípio da continuidade histórica. Mesmo no tempo do $3^{\circ}$ Reich já esse sentimento parece ter sido singularmente agudo entre os que emigraram, o que não pode aliás surpreender. Em obra bem conhecida de Horkheimer e Adorno, que se imprimiu primeiramente em 1944 nos Estados Unidos, encontram-se, com frequência, destas expressões: "esquecimento racionalizado", "adoecer da experiência", "ódio ao passado", "ausência de sentido, hoje, da lembrança consciente e da memória involuntária". Ou passagens como esta:

"Os indivíduos reduzem-se a meras sequências de coisas presentes que não deixaram rastro, ou melhor, cujos rastros eles detestam por irracionais, supérfluos e literalmente ultrapassados no juizo dos homens".

E mais de vinte anos depois, ao falar das observações de Heimpel sobre o atrofiamento do senso da continuidade histórica na Alemanha, Adorno julga-o sintomático da condição descrita naquela obra de 1944 (52). Mas embora observe que a presença e a consciência da desconti-

(51). - Hermann Heimpel, Der Mensch in seiner Gegenwart, 2a. ed., Göttingen. Vandenhoeck \& Ruprecht, 1957, págs. 200 e seg.

(52). - Max Horkheimer e Theodor W. Adorno, Dialektik der Aufklärung. Francforte-sobre-o-Meno. S. Fischer Verlag, 1969, págs. 225 e seg.; Th. W. Adorno, Eingriffe. Francforte-sobre-o-Meno. Suhrkamp Verlag, 1966, pág. 128. 
nuidade são demasiado sensíveis em seu pais, Heimpel não chega a oferecer uma noção positiva do descontínuo na História. Gostaria até, como se mostrou, de ver erigida uma ponte sobre 0 abismo do $3{ }^{\circ}$ Reich, que fosse capaz de abolir a descontinuidade na história alemã.

Pouco mais tarde o problema é retomado na velha e prestigiosa Historische Zeitschrift pelo seu próprio diretor, e já agora, a presença do senso da descontinuidade não surge como fato lastimavel, que é preciso superar, mas como acquisição necessária da historiografia. Nesse artigo de 1961 trata-se de uma consciência histórica nova, que

"se erige sobre a descontinuidade" (53).

Em trabalhos posteriores volta o autor ao mesmo tema, que tambem fora abordado em 1958 por Wittram em livro sobre o interesse na História, onde já se falava no abalo sofrido pela crença em um sentido e fim da História, em sua continuidade e em sua íntima coesão. Outro historiador, Fritz Wagner, tambem insistirá no terrivel exemplo oferecido pela história alemã do decênio principado em 1930, e que não é possivel interpretar completamente enquanto ficarmos presos às coerências tradicionais e a sucessos já utrapassados.

"A continuidade que o historiador costuma usar para compreender os acontecimentos", acrescenta, "viu-se em nosso tempo convertida num problema ontológico muito discutido" (54).

Mas Wagner acredita, por outro lado, que o colapso de 1945, único e sem termo de comparação possivel com qualquer outro desastre suportado pela Alemanha ao longo de sua existência milenar, pode sujeitar-se a uma vigorosa lei de continuidade que, apesar de tudo, pairaria acima desse abismo. $O$ desenvolvimento da sociedade industrial continuou a efetuar-se, só que num ritmo mais acelerado, na República Federal Alemã, sem embargo da catástrofe política. E a burocratização da vida pública, a fusão da sociedade com o Estado, são promovidas em toda parte pelas forças econômicas e políticas, como se não houvesse nenhuma diferença de regime político e de estruturação social. A cesura introduzida pela catástrofe de 1945 só significou, ao cabo, um absoluto ponto final, se encarada do prisma histórico da política nacional. $O$ estudioso da história alemã pode voltar-se para

(53). - Theodor Schieder, "Grundfragen der neuen deutsche Geschichte". Historische Zeitschrift, n⿳ 192, págs. 1 a 16.

(54). - Theodor Schieder, Geschichte als Wissenschaft. Munique-Viena. R. Oldenbourg, 1968, pág. 11 e passim. 
outras continuidades, que nada têm a ver com a político-militar. Mas há de ter presente, ainda uma vez, esta dúvida: o próprio triunfo da continuidade não estaria posto, no fundo, em questão, desde que um progresso técnico, que tudo envolve, nos colocou diante dos olhos a perspectiva do suicídio da humanidade? Quando se reporta ao pronunciamento de Schieder, é ainda com hesitação que F. Wagner admite a idéia de que a discontinuidade já seria uma "categoria geral do pensamento humano de hoje". Categoria? Não seria melhor relaciona-la, com sentido histórico mais preciso, à dimensão do "tempo", onde podem residir tanto a descontinuidade como a continuidade? A seu ver, a tensão incessante entre os dois princípios é um dado que já não se pode ignorar do ponto de vista da teoria do conhecimento (55).

Parece-lhe característica, neste caso, a ironia de Fernand Braudel, quando fala naquele "sacrossanto princípio da continuidade", que prevalece entre historiadores ortodoxos. Ou ainda o sarcasmo do mesmo Braudel quando trata das tentativas de explicação histórica definidas por analogia com a idéia de evolução nas ciências naturais, apesar de ser levado a um ajuste de contas com seu temperamental amigo Georges Gurvitch, que exorbita, por sua vez, desenvolvendo uma sociologia ahistórica, toda feita de saltos, rupturas e insulamentos. Poderia lembrar que, em 1953, na aula inaugural do Colégio de França, já se perguntara Braudel sobre se o "imenso problema" da continuidade e descontinuidade do destino social, debatido pelos sociólogos, não seria antes de mais nada um problema da História. Com efeito, se os destinos humanos são partidos por grandes fraturas, se, no dia imediato a cada uma dessas rupturas, tudo volta a descansar em novos termos e de nada mais servem nossos utensílios e nossos pensamento de ontem e anteontem, a realidade dessas soluções de continuidade deve pertence à História (56). Para mostrar a importância crescente que, tambem fora da Europa continental, vai assumindo o problema entre estudiosos de História e de Filosofia da História, pode apontar-se, por exemplo, para o estudo em que John Randall Jr. observa como a História, ao implicar inovações, tambem implica descontinuidades ao lado de continuidades (57). Ou ainda para a comunicação lida em 1971 por Sir Herbert Butterfield acerca das descontinuidades entre as gera-

(55). - Fritz Wagner, Der Historiker und die Weltgeschichte. FriburgoMunique. Verlag Karfl Alber, 1965, págs. 101 a 104.

(56). - Fernand Braudel, Ecrits sur l'Histoire. Paris. Flamarion, 1969, págs. $30 \mathrm{e} \mathrm{seg.}$

(57). - John Herman Randall Jr., Nature and Historical Experience. Nova Iorque. Columbia University Press., 1958, pág. 326. 
ções, onde se mostra como essas rupturas tornam muito mais dificil o registro dos traços microscópicos da mudança histórica (58).

Esses traços "microscópicos" encerram uma referência a Namier, de cujas obras Sir Herbert constantemente discordou, mas agora encontra meios de enaltece-la. Não que o seduzam a história miuda, as intermináveis contagens de eleitores o!̣ a atenção dada a multidões de figuras secundárias, mas por achar admiravel a nitidez com que o historiador da era de Jorge III sabe redescobrir a mentalidade política do tempo estudado, vencendo incompreensões e os anacronismos acumulados pelas clivagens que desde então se sucederam. Contudo no livro mais célebre de Sir Herbert Namier, escrito entre as duas guerras mundiais, não sente seu autor a necessidade de formular um conceito preciso de descontinuidade na História, e nem me consta que tal conceito apareça mencionado em outros escritos seus. E preciso voltar à Alemanha e, por sinal, à Alemanha nacional-socialista, para encontrar precisões curiosas sobre o problema, em comunicação lida por Erich Brandenburg, onde se trata das pausas, dos saltos, dos hiatos, que interrompem a continuidade histórica. Apresentado em 1941 à Academia de Ciências da Saxônia, sob o título de "o conceito de evolução e sua aplicação à História" (59), o trabalho do conhecido historiador desmonta peça por peça, com uma argumentação cerrada, as concepções "organológicas", que distinguem na História uma unidade, por analogia com o crescimento das plantas. $\mathrm{O}$ que ele próprio encontra são indivíduos que atuam e reatuam e inovam, desmentindo assim a pretensa unidade que resulta da transposição enganadora, para a ciência da História, de uma noção que só tem lugar na biologia e, mais precisamente, na ontogênese.

A tese de Brandenburg, autor que, se não pertence, segundo parece, aos turiferários do $3^{\circ}$ Reich, tambem não figura entre aqueles que abertamente o hostilizaram, sugere que o campo de preocupações dos que vislumbram o valor do princípio da descontinuidade para a boa inteligência do passado, poderia descortinar-se tambem independentemente das experiências da emigração. A ênfase que nela se dá aos indivíduos excepcionais, aos herois, aos grandes inovadores e criadores, aproxima-o menos dos pensadores da escola de Francforte, como Adorno e Horkheimer do que, talvez, de um Treitschke, onde se refere aos homens que fazem a História. De sorte que seria vão querer ir buscar uma única origem e uma só explicação para tendência as que se vêm

(58). - Sir Herbert Butterfield, The Discontinuities between the Historical Generations. Cambridge. At the University Press, 1972, pág. 7.

(59). - Walter Hofer, Geschichtschreibung und Weltanschauung, cit. pág. 515. 
firmando um pouco por toda parte. E neste ponto não é possivel esquecer a contribuição singularmente valiosa que ofereceu Alexander Gerschenkron, no sentido de clarear essas tendências, com a elucidação de alguns dos diferentes significados que podem assumir os conceitos de continuidade e descontinuidade em História (constância de direção, periodicidade dos acontecimentos, mudança endógena, etc.), ainda quando, em alguns casos, sejam mais particularmente aplicáveis à História econômica, a especialidade do mestre de Harvard (60).

E importante notar que, para o historiador e economista russo-americano, tanto a continuidade, como a descontinuidade, deveriam considerar-se como instrumentos forjados pelos estudiosos do passado, e não como alguma coisa de inerente à matéria histórica e invariavelmente contida nela. $O$ recurso a qualquer desses instrumentos há de proceder, sem dúvida, de uma decisão arbitrária, da arbitrariedade peculiar ao próprio processo de cognição, mas apesar disso, o enfoque do desenvolvimento histórico como sequência de mudanças inteligíveis nos padrōes de crescimento, que se fazem modo paulatim, modo saltatim, ajudará a arrumar os dados empíricos de tal maneira que se torne eventualmente possivel alcançar resultados significativos e dignos de interesse, mesmo quanto não sejam positivos e definitivos. $O$ importante é saber delimitar e adequadamente formular tais conceitos, tendo sempre em conta que hão de ser entendidos como conceitos propriamente históricos, não matemáticos, por exemplo, nem metafísicos.

Um exame pormenorizado das conclusões a que chega Gerschenkron nesse particular poderia estender esta digressão para muito alem do tema do presente trabalho. Entretanto o estudo do problema da descontinuidade em História não leva forçosamente tão longe quanto possa parecer do objeto aqui proposto. O certo é que Ranke vislumbrou esse problema e soube caracteriza-lo de certo modo em uma fórmula que tanto se celebrizou como a do wie es eigentlich gewesen, essa frase que, na opinião ainda de Gerschenkron, saiu

"da pena de um grande historiador e depois acabou perdendo o significado quando repetida ad nauseam por um sem número de mediocridades" (61).

E ao tratar das épocas da história moderna, nas suas palestras de Berchtesgaden que, tendo mencionado a opinião corrente de que, em

(60) . - Alexander Gerschenkron, "On the Concept of Continuity in History", Continuity in History and Other Essays. Cambridge. Mass., The Belknap Press of Harvard University Prses, 1968, págs. 11 a 39.

(61) . - Alexander Gerschenkron, Continuity in History. . . cit. pág. 126. 
História, cada época só ganha mais alto sentido na medida em que apareça como etapa de transição para a seguinte, ele exclama com a segurança de quem manifesta uma convicção bem assentada:

"Eu afirmo, porem, que cada época é imediata a Deus".

Nessas palavras e na argumentação que pretende explica-las, assim como em muitas páginas de sua obra, o que se expressa é a reação de Ranke contra uma das tendências do historismo, que se encontra em germe já na obra pioneira de Herder, onde as sociedades humanas são concebidas à imagem dos organismos. $O$ valor de cada época, acrescenta, não se encontra de modo algum naquilo que dela possa ter resultado. Descansa, sim,

"em sua mesma existência, naquilo que ela efetivamente for".

E ainda ajunta que, por essa forma, a visão da História e, de fato, da vida individual ao longo da História, adquire notavel riqueza e poder de sedução.

Essa crítica à idéia da continuidade implícita nas concepções "organológicas" de que falou Brandenburg, não pretende apresentar-se, contudo, de forma dogmática e exclusivista. Ao dizer expressamente que a atenção do historiador deve concentrar-se antes de tudo sobre como pensaram e viveram os homens nesta ou naquela época, já que cada época tem em si mesma sua justificação e seu valor, não pretende Ranke afirmar que se devam desconhecer as diferenças entre as várias épocas e a sucessão delas. Estas considerações, porem, vão para um segundo e um terceiro plano. De qualquer modo, não há muito lugar em seu pensamento para a idéia do progresso, ou antes para a religião do progresso, tal como era professada em seu século, embora tenha por certa a existência de um progresso limitado principalmente ao campo material e tecnológico. O que sobretudo lhe parece escusado admitir é a idéia de um crescimento retilíneo para as sociedades humanas:

"eu não afirmaria que o progresso se faz numa linha reta", declara em seu curso de 1854, "mas (se faz) antes ao modo das torrentes que, por conta própria, vão abrindo seu caminho".

Como quem dissesse que não se pode bem prever ou prevenir esse caminho.

O pensamento de que cada tempo vale por si mesmo e de que só a um nivel mais baixo pode importar ao historiador o encadeamento necessário das coisas ao longo das eras, alia-se estreitamente à deliberada renúncia a uma demanda de sentido (fim) para a História. Semelhante renúncia liga-se, por sua vez, àquela porfia em querer 
observar e mostrar o passado com isenção, alheia a amores e rancores próprios da condição humana. No ambiente espiritual que dominou o século XIX, não seria muito facil distinguir uma quase imperceptivel travação entre as idéias centrais de Ranke, sobretudo se vasadas em alguma daquelas suas fórmulas que mais facilmente ganharam notoriedade e que, de fato, já parecem célebres de nascença. Em não poucos casos, tais fórmulas não deixavam apreender seu significado inteiro, devido a uma ambiguidade talvez proposital, ou mesmo por causa da má formulação. E quando fossem mal ou bem entendidas, tão frontalmente contrariavam o sentir dos contemporâneos, e seus hábitos mentais adquiridos, que não lhes faltariam revides.

Lamprecht, por exemplo, que tem a superstição do progresso como fatalidade inarredavel, não se cansará de denunciar o próprio afã de neutralidade, que no pensamento rankeano é inseparavel do ofício de historiador. A um primeiro relance, nada há nesse princípio de perfeita isenção do pesquizador - que se diria científico - capaz de infringir a lei do progresso. O descompasso entre as duas posições faz-se, porem, flagrante, quando ao wie es gewesen. ... "como foi efetivamente", opõe Lamprecht um wie es geworden..., isto é "como se tornou" ou, mais exatamente, "como deveio", onde parece mais claramente indicada uma idéia de transição que não se interrompe. A consideração de cada época segundo o que ela por si valha, no que tenha de viva presença, não no que prorrogue e prometa, cede o primeiro lugar, que lhe dava Ranke, ao de um desenvolver-se ininterrupto, e então temos verdadeiramente a apoteose da continuidade. Por outro lado fica bem clara aqui a íntima conexão das duas mais célebres fórmulas rankeanas, que se apresentam como duas faces de um só e único pensamento. Quem queria mostrar o passado sem sucumbir às paixões terrenas, aspirava naturalmente a contempla-lo sub specie aeterni ou, em suma, a ve-lo como Deus o deveria ver:

“... do ponto de vista de Deus, todas as gerações são igualmente justificadas, e é preciso que assim tambem as veja o historiador".

Apesar de tudo, haveria com certeza boa dose de exagero no pretender que Ranke anteviu com nitidez algumas questões que hoje ocupam mais vivamente os historiadores, e que por essa forma ele assumisse papel de precursor. E inegavel porem que uma constante meditação sobre problemas de seu ofício, levando-o a não se conformar tranquilamente com idéias então dominantes, abriu-lhe os olhos para a possibilidade de soluções que estariam mais fora do alcance de outros estudiosos. Com isso, com seu exemplo, às vezes com suges- 
tões suas, terá contribuido para que entre seus herdeiros e sucessores permanecesse a mesma capacidade de meditação e de insatisfação. Seria explicavel, assim, o fato de que exista até hoje muita coisa de atual em sua inatualidade. Não chegou, para citar um exemplo, a elaborar uma teoria precisa das gerações históricas, mas é a partir de sementes que lançou, e já em sua primeira obra, que seu discípulo Ottokar Lorenz, retomou a matéria, e esta será desenvolvida principalmente de 1926 em diante nos estudos de Wilhelm Pinder sobre as gerações na História da Arte. Seria possivel ir mais longe se pudéssemos situar Ranke entre os antecipadores da chamada história estrutural, que vem ocupando alguns autores na Alemanha, e não só na Alemanha? Já em 1954 procurou Otto Brunner mostrar a diferença entre História social e História política, ao dizer da primeira que, em contraste com a segunda, vê antes de tudo a arquitetura interna, a "estrutura" das sociedades, embora entenda que não nos é dado conhecer as estruturas relativamente duradouras independentemente do exame dos acontecimentos políticos (62).

Brunner não menciona ainda o nome de Ranke no estudo que escreveu sobre o problema da história social européia, mas reportando-se mais tarde a esse estudo e tambem ao de Werner Conze sobre a "historia estructural da era técnico-industrial", publicado em 1957, Theodor Schieder acentua expressamente o fato da historiografia rankeana dar muito menor ênfase à ação anônima das individualidades isoladas do que às vastas estruturas impessoais que com elas se identificam e de que o Estado é exemplo notavel, mas não o único (63). A dificuldade maior que neste caso se apresenta, muito maior ainda do que a proporcionada pelos problemas relacionados com a continuidade-descontinuidade, consiste no fato de a própria conceituação de estrutura variar quase tanto quanto as disciplinas ou até quanto aos próprios autores que costumam recorrer aos seus préstimos. A essa noção não eram alheios, na Alemanha, os estudos de história ou filosofia da História de Dilthey mas o certo é que a maioria dos historiadores alemães de hoje parece andar a procura de caminhos que os apartam muito daqueles que lhes poderia abrir Dilthey, pois o que frequentemente querem não é uma dissociação, é antes uma conciliação ou um contraponto do típico e do individual. Alem disso, pouco há de comum entre a categoria diltheyana, construida em fins do século passado, e os modernos estruturalismos dos linguistas, dos economistas ou dos antropólogos. Ou mesmo entre as definições de "es-

(62). - Otto Brunner, "Das Problem einer Europäische Sozialgeschichte", Neue Wege der Sozialgeschichte. Göttingen. Vandenhoeck \& Ruprecht, 1956, pág. 9.

(63). - Theodor Schieder, Geschichte als Wissenschaft. Munique-Viena. R. Oldenbourg, 1968, pág. 162 . 
trutura" em Nadel, Parsons, Radcliffe Brown ou Levi-Strauss, para só citar uns poucos exemplos. Quase sempre resultam estas de teorias elaboradas numa perspectiva estática, quando muito estavel, que não se integram no tempo senão com dificuldade. Nessas condições podem tornar-se tão incompatíveis com o processo histórico que é o caso de perguntar se a expressão "história estrutural" não encerra um contra-senso.

Para superar a incompatibilidade seria mister redefinir o conceito, de modo a que o tempo cesse de ser exterior às realidades estudadas e se confunda enfim com a própria estrutura. Foi um pouco o que fez Fernand Braudel quando quís historizar esse conceito. Da História em três níveis, que distingue, a primeira, "quase imovel", visa ao homem nas relações com seu meio. A segunda, que já comporta maior grau de mobilidade, é uma "História lentamente ritmada", que trata dos grupos e agrupamentos sociais, permitindo, por exemplo, estudar as economias e os Estados, as sociedades. as civilizações, até mostrar como essas vagas profundas podem operar no domínio da guerra, que não depende só das vontades individuais. E há por fim a História tradicional, das oscilações breves, rápidas, nervosas, dimensionadas pelo indivíduo, não pelo homem: agitação de superfície, vagas que a maré eleva em seu movimento possante: a História eventual (événementielle) de Simiand (64). Mas é na segunda, a História em ritmo lento, que têm seu lugar a noção de estrutura e os problemas da "longa duração".

Não obstante as aproximações tentadas por Fritz Wagner e principalmente Theodor Schieder, exemplos como esse e outros aqui alvitrados, levam-nos longe do historismo tradicional, que Ranke representa, ainda que em alguns pontos o ultrapassassem. Contudo será legítimo perguntar se as novas ou talvez as futuras gerações de historiadores ganhariam em mostrar-se totalmente refractárias à mentalidade que ele representou. A esse propósito justificam-se estas observações de Schieder:

"O historismo em sua velha forma entrou no ocaso. No entanto deixou marcas fundas, e sem o saldo das suas idéias não poderiam sobreviver nem a ciência da História, nem a historiografia. A esse saldo indispensavel pertence o pensamento de que as necessidades do homem, assim como os valores $e$ as normas

(64). - Fernand Braudel. La Méditerranée et le Monde méditerranéen d l'Epoque de Philippe II. Paris. Librairie Armand Colin, 1949, págs. XIII e seg. 
que o homem estabeleceu, se sujeitam à lei da mudança histórica e, em suma, existem apenas em formas mutáveis" (65).

Poucos negarão, por outro lado, que com ele de algum modo se restringiu o campo visual dos historiadores alemães, deixando fora de seu alcance territórios de riqueza mal suspeitada por eles, e que os de outros paises, valendo-se de outras armas, não tardariam a ir explorar. A consciência desses limites, agravada ainda mais pela ação devastadora do nazismo, e o espírito de emulação provocado por aqueles exemplos estrangeiros, fizeram com que se generalizasse na pátria de Ranke uma tendência para a revisão das posições antigas. $O$ vivo desejo de dar orientação nova ao trabalho histórico, se levou alguns a irem inspirar-se em tais exemplos, fez com que outros fossem tentados a procurar um guia na própria tradição nacional. Houve mesmo quem chegasse a falar numa quase vitória póstuma de Lamprecht que, com seus métodos "morfológicos", se contrapôs à "escola" histórica alemã e tentou uma aproximação com as correntes supostamente positivistas da Europa ocidental.

Essa volta a Lamprecht, que não passou, aliás, de rebate falso, resultaria numa atitude mais anacrônica ainda do que a volta a Burkhardt, ou a volta a Droysen, antes apregoadas, por se referir a um autor mais estreitamente preso do que estes a aspirações da época em que viveu, e que hoje não têm sentido. Otto Hintze que, sem ter formado na parcialidade de Lamprecht, ao tempo da Methodenstreit, admitiu a importância de algumas das suas idéias, mostrou então como elas podiam enriquecer, sem deita-la por terra, a tradição fecunda e gloriosa do historismo que, infenso, por sua natureza, a pretensões dogmáticas, pode renovar-se sem dificuldades maiores. Pertencentes, embora, a um contexto diverso, é de notar que alguns pontos de vista do próprio Hintze, que morreu em 1940, se assemelham a certas definições de Braudel. Mormente quando descreve sua história em dois níveis, ou duas formas rítmicas fundamentais, comparáveis aos três ritmos de que fala o historiador francês (66). Segundo a teoria de Hintze, há um ritmo, o evolutivo, que se passa sobretudo no domínio do inconsciente e do instintivo, enquanto o outro, que seria o dialéti-

(65). - Theodor Schieder, Geschichte als Wissenschaft, cit., pág. 152.

(66). - Otto Hintze, Soziologie und Geschichte. Göttingen. Vandenhoeck \& Ruprecht, 1964, pág. 348. - Em artigo de 1959 reconhece aliás o próprio Braudel a importância da obra de Hintze, quando diz: "Otto Hintze, a quem se teria dado entre nós o alto lugar que ele merece, se as suas obras completas não tivessem saido em tão má hora: 1941 e 1942", Fernand Braudel, Ecrits sur l'Histoire cit., pág. 176. Deixou de existir já este último obstáculo à difusão maior dos trabalhos de Hintze, desde que, em 1962, começou a ser reeditada sua obra. 
co, depende mais de fatores conscientes e espirituais. Aquele move-se de maneira mais coerente e constante, este em contrastes ríspidos, que reiteradamente vão emergindo e imergindo.

E assim como Braudel recorre à analogia das águas fundas e águas de superfície, para mostrar a diferença entre uma História vagarosamente ritmada, onde cabem as estruturas e a longa duração, e outra feita. de acontecimentos instantâneos, imprevistos, vibrateis, a História événementielle em suma - Hintze vai procurar seus termos de comparação na geologia antiga, com as teorias dos netunistas e vulcanistas. Aqui, escreve,

"opera a força lenta e constante das águas, a produzir as estratificações sedimentares; alí agem os efeitos súbitos, explosivos, das forças vulcânicas, com suas formações eruptivas e cristalinas".

Sustenta' que, assim como só pôde formar-se a crosta terrestre mediante uma combinação das duas dinâmicas, a realidade histórico-social depende de uma cooperação entre os movimentos evolutivo e dialético. Nenhum deles basta só por si, ambos fazem-se necessários para a boa inteligência do processo histórico. Este

"não obedece a rígidos padrões lógicos, mas corresponde antes a esquemas cambiantes, muitas vezes fugitivos e inconsequentes, que se reduzem aproximadamente às duas formas fundamentais acima caracterizadas". E acrescenta: "O produto mais claro e mais importante desse modo de ver, oferecem-n'o as chamadas idéias históricas, aquelas tendências reais-espirituais de que Ranke gostava de falar...".

Alguns dos temas já prenunciados por Hintze, como o dos fatores conscientes e inconscientes, do individual e coletivo, da continuidade e descontinuidade, incluem-se, bem como a idéia de estrutura, entre os que têm sido com frequência propostos, nos últimos tempos, pela historiografia alemã. Foge à finalidade da presente introdução, mas foge sobretudo à competência de quem a redige, uma resenha das tendências dessa historiografia. Baste, a título de exemplo, lembrar a singular importância do monumental Léxico dos Conceitos Fundamentais da História, já em curso de publicação, sob a direção de Otto Brunner, Werner Conze e Reinhart Kosellek, que, alem de revelar a notavel vitalidade daquelas tendências, é uma demonstração de como se pode remoçar, sem trai-lo, o espírito da "escola" histórica alemã. Nas mais de novecentas páginas de seu primeiro volume, único im- 
presso até aqui (67) entre cinco previstos, abrangendo pouco mais de vinte verbetes (v. g. Aristocracia, Empregados, Antisemitismo, Trabalho e Trabalhador, Era das Luzes, Autoridade, Camponês, Burguesia, Cristianismo, Democracia, Ditadura...), já se justifica amplamente a originalidade da sua concepção, que o distingue de outras iniciativas congêneres e, em particular, dos dicionários filológicos e filosóficos conhecidos. Não the importa, com efeito, dar um elenco exaustivo de definições, que podem ser encontrados em manuais especializados ou trabalhos metodológicos, mas tão somente apresentar as noções historicamente mais significativas, tratadas em artigos de 20 a 60 páginas cada um, em grande formato. Alguns desses artigos podem desenvolver-se eventualmente em livros separados, como já aconteceu pelo menos com o verbete sobre "Sociedade Civil", de autoria de Manfred Riedel, de Heidelberg.

A temática central é a da passagem da era moderna para a era contemporânea, onde se abrange a ruptura revolucionária dos séculos XVIII e XIX que, por sua vez, correspondeu a uma revolução no mundo das noções e de seus significados. Isso explica a preferência dada ao período que aproximadamente se estende de 1700 até quase os nossos dias. A originalidade da concepção do léxico prende-se estreitamente ao querer mostrar a transformação das noções, de maneira que a experiência nelas condensada permita esclarecer os aspetos teóricos. Não se pretende, contudo, oferecer definições abstratas e exteriores à História, que pudessem prescindir das mudanças de significação ao longo do tempo. Especialmente interessante, a esse propósito, é toda a parte da introdução geral onde se explica o tipo de abordagem da diferença entre a palavra e o conceito. Nela se mostra, por exemplo, que

"uma palavra contem possibilidades de significação; o conceito reune em si plenitudes de significados. Assim sendo, um conceito pode ser claro, mas há de ser plurívoco". Em suma, "as significações das palavras poderiam exatamente determinar-se por meio de definições, os conceitos só poderiam ser interpretados".

Serve de remate a toda essa passagem um pensamento ilustre:

(67). - Otto Brunner, Werner Conze, Reinhart Koselleck (direção). Geschichtliche Grundbegriffe, vol. $1^{\circ}$ (A - D), Stuttgart, Ernst Klett Verlag, 1972. 
"Todos os conceitos em que, do ponto de vista semiótico, se congregue todo um processo, esquiva-se à definição: só o que não tem história é definivel".

Nada destoa vivamente, nessa concepção, da tradição espiritual que Leopold von Ranke representou em grau eminente, renovada, embora, e enriquecida, para atender às mais recentes, exigências do trabalho histórico.

SÉRGIO BUARQUE DE HOLANDA. Nasceu em 11 de julho na cidade de São Paulo. Formado em 1925 pela Faculdade de Direito da Universidade do Rio de Janeiro, afeiçoou-se no entanto, desde cedo, às atividades literárias, atuando no Movimento Modernista iniciado em São Paulo em 1922 e fundando, com Prudente de Morais Neto, a revista Estética, publicação de "grande influência na renovação dos estilos literários e artísticos do Brasil".

Exerceu tambem durante algum tempo o jornalismo e foi na qualidade de correspondente de uma agência internacional noticiosa que percorreu a Europa, detendo-se por alguns anos na Alemanha.

De sua atuação como crítico do Diario de Notícias no período 1940-41 resultaria o livro Cobra de Vidro, que, publicado em 1944, reuniu parte das apreciações contidas naquele noticioso.

A carreira profissional levou-o à chefia da seção de publicações do Instituto Nacional do Livro (1938) e à direção da Divisão de Consulta da Biblioteca Nacional. Foi diretor tambem do Museu Paulista e do Instituto de Estudos Brasileiros da Universidade de São Paulo (1962-1964).

Eleito em 1945 presidente da Associação Brasileira de Escritores, seção do Rio de Janeiro, exerceria ainda por duas vezes, em 1947 e em 1950, a presidência da seção paulista da mesma associação.

E membro da Academia Paulista de Letras, bem como de várias outras instituições culturais.

Sua iniciação no magistério deu-se logo após a fundação da Universidade do Distrito Federal, onde lecionou Cultura Luso-brasileira e História da América na Faculdade de Filosofia.

Em São Paulo foi professor de História Econômica do Brasil e de História Social e Política na Escola de Sociologia e Po- 
lítica (1948), tornando-se em 1956 responsavel pela cátedra de História da Civilização Brasileira da Faculdade de Filosofia, Ciências e Letras da Universidade de São Paulo, na qual se efetivou por concurso dois anos mais tarde. Daquela data, até a sua aposentadoria, concretizada em 1969, formaria várias gerações de estudantes, orientando-os com o seu exemplo e a rica experiência no caminho nem sempre suave, mas com certeza fecundo, da pesquisa histórica.

A convite da Universidade de Roma deu ali um curso de Estudos Brasileiros (1952-1954). Em 1963 a Universidade do Chile e seu Centro de Investigaciones de Historia Americana convidaram-no a ministrar um Curso e Seminário de História do Brasil.

Percorreu em 1965 várias universidades norte-americanas, participando de seminários nas de Colúmbia, Harvard e Califórnia.

Novamente nos Estados Unidos em 1966-67 foi professor-visitante na Universidade de Indiana e na New York State University, desempenhando atividades didáticas tambem em Yale.

Conferencista ativo no Brasil e no Exterior esteve na Sorbonne em 1949; na Suiça em 1954, onde nos Rencontres Internationales de Genève, sua conferência, Le Brésil dans la Vie Americaine, seguida de debates, foi publicada naquele mesmo ano.

Participou de três Comitês da Unesco em Paris (1949) relacionados com matérias de sua especialidade, tomando parte em 1950 no Primeiro Colóquio Internacional de Estudos Luso-Brasileiros reunido em Washington, e em 1966 no Sexto reunido em Cambridge, Mass. (Harvard) e Nova Iorque (Colúmbia).

Ainda a convite da Unesco esteve presente às reuniōes do Comitê de Estudo das Culturas Latino-Americans efetuadas em Lima (1967), em São José da Costa Rica (1968), e cidade do México (1974).

Foi adido cultural na Itália em 1954-1955.

Do intelectual que é, bastante se disse mas muito se pode dizer ainda. Reconhecidamente "um dos maiores historiadores brasileiros, pela formação cultural e filosófica, pelo conhecimento literário, pelo domínio da língua", sua obra exprime-lhe a riqueza de conhecimentos, a paciência, curiosidade e erudição do pesquisador e dá a medida de sua capacidade intelectual. 
Exemplifica-o largamente o primeiro livro, Raizes do Brasil, publicado em 1936 e do qual já se tiraram várias edições, entre elas, uma em italino e outra em espanhol. "Clássico de nascença", no dizer de Antônio Cândido, reveste-se de um "respaldo teórico" ligado à "nova história social dos franceses, à sociologia da cultura dos alemães, a certos elementos da teoria sociológica e etnológica", inéditos entre nós à época: - "No tom geral, uma parcimoniosa elegância, um rigor de composição escondido pelo rítmo despreocupado e às vezes sutilmente digressivo, que faz lembrar Simmel".

A abuntante produção posterior confirmariam plenamente as qualidades do livro inicial. Seria difícil cita-la toda. Fiquemos portanto em algumas das muitas obras que suscitaram a admiração e o respeito dos estudiosos: Monções, que surge em 1945; A Expansão Paulista do século XVI e Começo do Século XVII (1948); Caminhos e Fronteiras (1957); Visão do Paraiso (1959).

Sérgio Buarque de Holanda dirige a História Geral da Civilização Brasileira que se vem publicando desde 1960 com a participação de larga equipe de especialistas e na qual colaborou com vários artigos. E o autor por inteiro do último volume dessa Coleção, publicado em 1972: O Brasil Monárquico - Do Império a República, que em suas 435 páginas revela ainda uma vez o historiador que todos conhecemos e admiramos (*).

(*). - Nota bio-bibliográfica elaborada pela Profa. Suely Robles Reis de Queiroz. (Nota da Redação). 